NBER WORKING PAPER SERIES

\title{
TERMS OF TRADE SHOCKS AND ECONOMIC PERFORMANCE 1870-1940: PREBISCH AND SINGER REVISITED
}

\author{
Yael S. Hadass \\ Jeffrey G. Williamson \\ Working Paper 8188 \\ http://www.nber.org/papers/w8188 \\ NATIONAL BUREAU OF ECONOMIC RESEARCH \\ 1050 Massachusetts Avenue \\ Cambridge, MA 02138 \\ March 2001
}

We acknowledge the assistance of Ximena Clark and Michael Clemens on related projects and some of the underlying data base for this one. Conversations with Luis Bertola, Joan-Ramon Borrell, Dick Cooper, Arnaud Devleeschauwer, Juan Carlos Hallak, Peter Lindert, Marc Melitz, Kevin O'Rourke, Dwight Perkins, Frederic Pivetta, Leandro Prados, and Andrew Warner improved the argument. So did the econometric advice of Francesco Caselli and Jack Porter, although they are not to blame if we ignored it. We also acknowledge the useful feedback from seminar and conference participants at the University of Copenhagen (December 8-9, 2000) and Harvard University (February 7, 2001). In addition, Williamson acknowledges with pleasure the generous support of the National Science Foundation SBR-9505656 and SES-0001362, and both authors thank the Harvard Center for International Development for allocating office space to the project. The views expressed herein are those of the authors and not necessarily those of the National Bureau of Economic Research.

(C) 2001 by Yael S. Hadass and Jeffrey G. Williamson. All rights reserved. Short sections of text, not to exceed two paragraphs, may be quoted without explicit permission provided that full credit, including (C) notice, is given to the source. 
Terms of Trade Shocks and Economic Performance 1870-1940:

Prebisch and Singer Revisited

Yael S. Hadass and Jeffrey G. Williamson

NBER Working Paper No. 8188

March 2001

JEL No. F1, N10, O1

\begin{abstract}
Debate over trends in the terms of trade between primary commodities and manufactures, their causes and their impact has dominated the literature for more than a century. Classical economists claimed that the terms of trade of primary commodities should improve since land and natural resources are always in inelastic supply. Following the Great Depression, a new view emerged. What came to be known as the Prebisch-Singer thesis was instead that the terms of trade for primary products had deteriorated up to the 1950s. The subsequent literature has almost exclusively and obsessively asked whether a deterioration has actually taken place over the 130 years following 1870. Nowhere in this literature has the impact of these terms of trade shocks on long run growth been assessed, although it is certainly full of lively speculation and debate. This paper fills part of this empirical gap by constructing a country-specific panel data base 1870-1940, by documenting terms of trade trends by country and region, and, finally, by estimating the impact of the price shocks on long run economic performance. We find the impact to have been asymmetric between center and periphery.
\end{abstract}

Yael S. Hadass

Department of Economics

Littauer Center, Room 200

Harvard University

Cambridge, MA 02138

and Center of International Development

yhadass@fas.harvard.edu
Jeffrey G. Williamson

Department of Economics

216 Littauer Center

Harvard University

Cambridge, MA 02138

and NBER

jwilliam@kuznets.fas.harvard.edu 


\section{Introduction}

Debate over trends in the terms of trade between primary commodities and manufactures, their causes and their impact has dominated the trade and development literature for more than a century. Classical economists ${ }^{1}$ claimed that the terms of trade of primary commodities should improve over time, since land and natural resources are in inelastic supply. In the early 1950s Raoul Prebisch $(1950)^{2}$ challenged this benign view by alleging that the terms of trade of the primary-product-producing Third World had deteriorated and would continue to deteriorate as long as they specialized in primary products. While faster technological progress in manufactures might be expected to cause a rise in the price of primary products relative to manufactures, Prebisch argued that the data showed the contrary. According to Prebisch, only 63 percent of the finished manufactures which could be bought with a given quantity of primary products in the 1860 s could be purchased in the 1930 s.

This alleged secular decline in the terms of trade of primary products from the 1870 s to the $1930 \mathrm{~s}$ was used to help explain the widening income gap between what became known as the center and the periphery. The argument supported the policy move towards Third World autarky in the 1940s, 1950s and 1960s, a highly interventionist industrialization policy choice which was eventually called import substitution. One of the advocates of this policy was Hans Singer, who claimed that even if the terms of trade of primary products improved, it would reduce the incentive for industrialization in developing countries while enhancing the incentive to produce more primary products (Singer 1950: p. 482). Fifty years later, the words we might use to describe this effect would be "industrialization crowding out" or "Dutch disease." Thus, while an improving terms of trade would have augmented incomes in the short run, a good thing, it would also have suppressed industrialization in the long run, a bad thing. Other economists have suggested the same result, but along different channels. Some have argued that resources

\footnotetext{
${ }^{1}$ An extensive list can be found in Diakosavvas and Scandizzo (1991: pp. 238-9).
}

${ }^{2}$ The 1950 paper has been reprinted many times, and the 1962 version is used here. 
are a "curse" to development, such that while an improvement in the terms of trade facing primary product exporters would increase the value of the resource base being exploited, poor growth would result. While economists haven't yet agreed on how the "resource curse" works, the recent empirical evidence brought to bear on it by Jeffrey Sachs and Andrew Warner (1995b) certainly confirms the correlation. One final example will serve: Aaron Tornell and Andres Velasco (1992) have suggested that resource abundant poor countries have undeveloped property rights such that terms of trade booms get translated into capital flight (a transfer of rents for safe keeping in rich countries), and, of course, Anne Krueger (1974) made the case for growth-suppressing rent-seeking long ago.

The modern terms of trade debate triggered by Prebisch and Singer spans a half century, and it can be organized around three questions. The first asks whether the empirical record confirms the alleged secular decline in the terms of trade of primary products. The second takes the secular deterioration in the terms of trade as given and asks why it took place. These two questions complement each other, of course, but the first has generated more empirical analysis and the second more theoretical. The third question asks what the short run and long run impact of the alleged terms of trade shock on primary producers has been over the past two centuries. It is fair to say that while many answers have been offered for the first two questions, almost none have been offered for the third, especially for the pre-World War II experience. The survey that follows is a prelude to this paper's research findings which deal with the third question. ${ }^{3}$

\footnotetext{
${ }^{3}$ This paper will deal with the combined short and long run impact of external relative price shocks on economies the world around 1870-1940. Ongoing research by Williamson alone will deal with deindustrialization in the periphery up the late $19^{\text {th }}$ century and re-industrialization thereafter, long before the activist Third World intervention in the 1950s. Among other factors, it will try to assess the impact of terms of trade shocks in this process.
} 


\section{The Facts and the Older Literature}

Prebisch used the Board of Trade price indexes for British imports and exports to represent world prices of raw materials and manufactured goods. The inverse of British net barter terms of trade (NBTT) led Prebisch to conclude that there was a secular deterioration in the relative price of primary products in the period 1876-1947. Figure 1 plots the Prebisch data, and they certainly support this position, at least up to the mid $20^{\text {th }}$ century. The later revisions by W. Arthur Lewis (1952: his total primary product prices series) are also plotted in Figure 1 and they roughly confirm Prebisch's assertions about the eight decades between 1870 and 1950 . Both series show a sharp erosion in the relative price of primary products up to the 1890s followed by a partial recovery up to World War I, a post-war collapse followed by a partial recovery in the mid-late twenties, and another collapse into the Great Depression followed by a (only partial in the Prebisch series) recovery after World War II. Since the recoveries after each of these three collapses are only partial, the relative price of primary products records a deterioration across the eight decades.

[Figure 1 about here]

Various authors have disputed the Prebisch claim. John Spraos (1980: pp.108-9) lists four major criticisms that have been raised about his data, his calculations and his inferences: (1) The United Kingdom's NBTT was not representative of the industrial world as a whole and hence its inverse could not serve as a proxy for the terms of trade of primary products (Kindleberger 1956: pp. 261-3, 1958; Meier and Baldwin 1957: p. 234; Haberler 1959: p. 20; Morgan 1959-60, 1963; Meier 1963: p. 59; Lipsey 1963: p.17; Johnson 1967: p. 249; Bairoch 1975: pp. 114-5); (2) Primary products imported by industrialized countries included commodities predominantly produced in developed countries, like wheat, beef, wool, and even cotton and sugar (Meier and Baldwin 1957: p. 235; Meier 1958, 1963: p. 59; Van Meerhaeghe 1969: p. 576; Frank 1976); (3) Exports are valued f.o.b. whereas imports are valued c.i.f., so the improvement in the United Kingdom's NBTT could be due partly or even wholly to a 
reduction in transport costs and not to a relative fall in the prices received by primary producers (Viner 1953: p. 114; Baldwin 1955; Ellsworth 1956; Meier and Baldwin 1957: p. 263; Meier 1958, 1963: p. 60; Haberler 1959: p. 20; Morgan 1959-60, 1963; Hyde 1963; Kenwood and Lougheed 1971; Streeten 1974; Bairoch 1975: pp. 115-9; Schloss 1977; Macbean and Balasubramanyam 1978: p.162); (4) Although new manufactured goods enter trade and the quality of existing manufactured goods improves, these developments are not adequately reflected in the price index of manufactures. This tends to bias upwards the drift in the manufactures price index and thus gives the impression of a deterioration in the relative price of primary products where none may have occurred (Viner 1953: p.114; Baldwin 1955; Ellsworth 1956; Meier and Baldwin 1957: p. 263; Meier 1958, 1963; Haberler 1959: p.21; Morgan 1959-60, 1963; Streeten 1974; Schloss 1977; Macbean and Balasubramanyam 1978: p. 162; Lipsey 1994).

The major contribution of the Spraos paper is that it begins to explore whether these points are significant empirically, and, in particular, whether they refute the deterioration inference. Regarding the first criticism, Spraos compares the difference between Prebisch's United Kingdom data set with another taken from the League of Nations ("Primary to Manufactured Commodities in World Trade", League of Nations 1945: p. 18). Spraos finds that, by his choice of a British series, Prebisch exaggerated the adverse trend for primary products, but the adverse trend was nonetheless still clearly present in the League's more appropriate OECD-based series. Regarding the second criticism, Spraos relies on the work of Robert Lipsey (1963) and Charles Kindleberger (1956), concluding that primary products of developing country origin have experienced a bigger price fall than those of New World origin, although the difference may not be significant given the sensitivity of such calculations to the choice of initial and terminal years. The main source of the third criticism is Paul Ellsworth (1956), who argued that all of the apparent deterioration in the NBTT of primary products between 1871 and 1905 could be accounted for by the decline in transport costs world wide, an event which, if big enough, could raise every trading partners' terms of trade. While Spraos concludes that this is a plausible interpretation of the evidence, he notes that the bias was far greater up to 1905 than afterwards since there was a slowdown in the decline in 
world transport costs during the interwar period (Isserlis 1938; Williamson 2000a: Table 1). Finally, while Spraos agrees there might have been a quality bias in the price data, there is simply no qualityadjusted price index currently available to deal with this issue properly, at least for the pre-1940 period. ${ }^{4}$

Other writers have used different data to study the trends in the terms of trade. W. Arthur Lewis (1952) used three data sets: prices of raw materials, foods and manufactures over the period 1876-1938.

There is a detailed description in Lewis's appendix (1952: pp.137-8) describing exactly how these series were constructed. They are based on prices of goods imported into the U.K. and U.S. and exports from the U.K., although Lewis makes an (in our judgment, inadequate ${ }^{5}$ ) effort to adjust them for changes in world transport costs. Figure 2 plots three of Lewis's terms of trade series, one for food products, one for raw materials, one for both (primary products: also in Figure 1), and all relative to manufactures. Each of the Lewis series documenting the relative price of primary products decreased over the seven decades before World War II, with the biggest decrease recorded in the world war decade 1910-1920. They made a significant recovery in the $1920 \mathrm{~s}$, almost reclaiming the late $19^{\text {th }}$ century peaks. The relative price then collapsed in early 1930s with the start of the Great Depression (Lewis 1952: p. 121).

[Figure 2 about here]

Surprisingly, Ellsworth (1956) has been one of the few analysts to use relative prices of imports and exports quoted in underdeveloped country markets. He took his data from United Nations publications. However, Ellsworth used an aggregate index for the price of primary to manufactured commodities in world trade, and thus did not explore each country's experience independently.

\footnotetext{
${ }^{4}$ Robert Lipsey (1994) did find that while the relative decline in primary product prices was weakened when he attempted to quality-adjust manufactures, it did not reverse the $20^{\text {th }}$ century trend.

${ }^{5}$ It appears that Lewis (1978: pp. 170-93, Appendix III) treated every tradable associated with every country by the same estimated freight rate adjustment (although he let it vary over time). Thus, he made no effort to identify freight rate changes which were, after all, quite country- and commodity-specific (there were bigger transport declines involving Asia than was true of the New World and the Middle East, and they were far bigger for low-value, high-bulk primary products than for manufactures and high-value primary products). Nor did Lewis take any account of changes in tariff policies which were, after all, quite country-specific (high and rising protection being the case in Europe and the New World, while free trade prevailed in Asia and the Middle East). In short, the Lewis estimates are in no way country-specific.
} 
Nevertheless, the Ellsworth index shows a deterioration between $1876 / 80$ and 1938 which matches the deterioration in ratio of U.K. primary imports to manufactured exports.

G. F. Ray (1977) uses four different indicators to explore the evolution in the relative price of primary products, but only two of them apply to 1870-1940: (1) "The Economist" commodity price indicator 1860-1976 measures, on a dollar basis, changes in the prices of selected freely traded commodities in world trade weighted by the import mix of OECD countries; (2) unit value indices, which cover manufactures and primary products, are taken from Alfred Maizels (1963: p. 80) for selected periods between 1876 and 1948 . Ray shows that primary product price trends between $1876 / 80$ and 1936/38 are sensitive to the deflator used. Both indices suffer weaknesses. First, unit values are likely to be a poor indicator of commodity prices (Ray 1977: p. 75). Thus, it is not clear that Ray's work was a significant advance over that of Lewis. Second, much depends on the terminal year when making conclusions about long run trends. Ray takes as an example the data in 1962 and shows that while the deflated Economist index records a considerable gain for the purchasing power of primary products relative to 1913 , the gain is much less when $1948 / 49$ is taken as the terminal point, and it becomes a loss if the comparison concludes with 1960.

Enzo Grilli and Maw Cheng Yang (1988) build a U.S. dollar price index for twenty-four internationally traded nonfuel commodities, covering almost all of the $20^{\text {th }}$ century, $1900-1986$. The basic version of this new index is base-weighted, with $1977 / 79$ values of world exports of each commodity used as weights. This new index covers the prices of 54 percent of all nonfuel commodities traded in the world in 1977/79 (49 percent of all food products, 83 percent of all nonfood agricultural products, and 45 percent of all metals). It therefore reflects the movements over time of international prices for a given basket of primary products. Two versions of the Grilli-Yang index are plotted in Figure 3, each representing an alternative index of manufactured goods prices. Figure 3 reveals two facts: first, that the relative price of primary products deteriorated across the $20^{\text {th }}$ century; and second, that there were two big disasters, one after World War I through the 1930s, and the other after the early 1970s through the 1980s. 
[Figure 3 about here]

While the work of Grilli and Yang was a significant advance over previous terms of trade measurement, one of the criticisms of their index is that U.S. tradable goods prices may be poor proxies for internationally traded goods. In addition, the relative prices implied by the Grilli-Yang data cannot be taken as an adequate proxy for the net barter terms of trade of developing countries $(\mathrm{Px} / \mathrm{Pm})$, because the export price index for developing countries (Px) contains more than simply primary commodities and the import price index of developing countries $(\mathrm{Pm})$ contains more than simply manufactures. Still, Grilli and Yang find that after 1900 nonfuel primary product prices declined substantially relative to those of manufactured goods sold in United States, as well as to those of manufactured goods exported by industrial countries. Their indices show a negative exponential trend of about 0.6 percent per annum over the 1900-86 period, but the decline was not uniform across nonfuel primary product groups. Metal and nonfood agricultural product prices (relative to manufacturing) show a much stronger long-term per annum trend decline than agriculture food prices ( 0.8 versus 0.4 percent). Thus, not all nonfuel primary product producers experienced the same fall in the purchasing power of their exports over the $20^{\text {th }}$ century. The export product mix has made a significant difference: the commodity "lottery" mattered, and some countries had luckier commodity draws than others (Diaz-Alejandro 1983). However, the GrilliYang indices all show pretty much the same booms and busts, and the timing is consistent with that reported earlier by Prebisch, Singer and Lewis.

We conclude this section on the older literature by pointing out that none of these authors have attempted to build a data set of commodity relative prices quoted in local markets in a way that would enable them to study the impact of relative price shocks on individual economies, an empirical assessment that is, therefore, absent from this literature. 


\section{The Newer Time Series Literature}

The newer time series literature tends to focus on the $20^{\text {th }}$ century. Michael Bleany and David Greenway (1993: p. 351) offer a useful survey of the approaches used, ${ }^{6}$ but their survey certainly makes it clear that much more sophisticated time series analysis has been achieved at the expense of much less attention to economic issues that started the debate.

Bleany and Greenway update the Grilli-Yang series to 1991 and conclude that there was a statistically (and, one supposes, economically) significant long-run downward trend in the ratio of primary product prices to those of manufactures, at about 0.5 percent per annum for non-fuel primary commodities. The magnitude and statistical significance of the trend varies according to the time span, a finding that even the older literature suggested based on the 1870-1950 experience (Figures 1-3). The price behavior of different categories of primary commodities is also sufficiently different to cast doubt on the validity of any conclusion drawn about long-term trends in the relative price of primary products as a group, a finding that should prove relevant to any country-specific assessment of impact. The main contribution of Dimitris Diakosavvas and Pasquale Scandizzo (1991) over previous studies is their treatment of a broader range of commodities with substantial disaggregation - fourteen individual primary commodities and five commodity aggregates - covering the period 1900-1982.

The development of unit root tests have been the basis for most of the recent terms of trade studies (e.g. Cuddington and Urzua 1989; Bleany and Greenway 1990; Powell 1991; Ardeni and Wright 1992) which have offered far more sophisticated treatment of the time series, but have excluded economic variables that might help explain relative price behavior and its impact. John Cuddington (1992), for example, applies modern time series techniques to the twenty-six individual commodity prices contained in the Grilli-Yang index of non-fuel commodity prices, allowing for the possibility of structural breaks

\footnotetext{
${ }^{6}$ See also Sapsford (1990), Sarkar and Singer (1991), and Sapsford and Balasubramanyam (1994).
} 
and the presence of unit roots. His study covers the period 1900-1983 and concludes that the majority (sixteen) are best characterized as trendless. Of the remainder, five had negative and five had positive trends. These findings suggest that a secular deterioration in primary commodity prices should certainly not be considered a universal "stylized fact" of the full $20^{\text {th }}$ century, once again suggesting that Third World country experience may have varied considerably, as did impact.

Cuddington highlights the tremendous diversity in both trends and cyclical behavior across commodity prices and stresses that univariate time series models ignore the role of additional variables that might capture the cause of particular shocks. An answer to Cuddington's criticism can be found in Harry Bloch and David Sapsford $(1996 ; 1997 ; 2000)$, who analyze movements in the terms of trade between primary product and manufacturers producers using a model that introduces the influence of relative wage movements in the primary and manufacturing sectors as well as the influence of mark-up pricing in manufacturing. Bloch and Sapsford estimate that over the period 1948-1986 a declining trend in the primary sector wages relative to manufacturing wages, compounded by a strongly rising mark-up in manufacturing, depressed the terms of trade by approximately 3 per cent per annum. Only strong growth in manufacturing output, which the authors estimate to have raised the terms of trade in excess of 4 percent per annum, saved primary producers after World War II from the dismal predictions made by Prebisch (Bloch and Sapsford 1996: p. 65). ${ }^{7}$

\section{Theory: Searching for Explanations}

Singer claimed that technological progress augments the demand for manufactures more than the demand for raw materials or food. He argued that technological progress in the center may increase

\footnotetext{
${ }^{7}$ While Bloch and Sapsford use only post World War II data, a time period outside the scope of the present paper, it would certainly be interesting to see whether their model would also be effective in explaining the pre-World War II years.
} 
income and thus product demand, but the demand for food will increase only slightly since the income elasticity of food demand is low, and that the demand for raw materials may even decrease if technological progress is strongly raw-material-saving. Thus, Singer predicted that technological progress would result in the long term deterioration in the relative price of food and raw materials. While Singer used classical thinking, Prebisch offered a Keynesian argument. An excess aggregate demand increases prices in upswings and excess aggregate supply decreases prices in downswings. Upswings increase wages in the developed countries due to competition between the producers and the pressure of labor unions. In downswings, wages are sticky. In the less developed countries, unions are weak and this prevents workers from getting higher wages in upswings and maintaining them in downswings. Thus, prices of manufactures rise more than prices of primary products in upswings, and decline less than the prices of primary products in downswings. This mechanism prevents the terms of trade from improving in the developing countries. Diakosavvas and Scandizzo (1991) offer a model to test the Prebisch hypothesis, relying on the idea that if the hypothesis of asymmetric response is valid, one would expect the elasticity of primary product prices with respect to manufactured goods prices to be larger on downswings than on upswings. Over the years 1900-1982, they find that the Prebisch hypothesis is supported by only five cases (nonfood, rice, cotton, rubber and copper). All other coefficients are insignificant. It appears, therefore, that the hypothesis of asymmetric changes in primary commodity prices is inadequate to explain the deterioration, if any, in terms of trade that occurred during periods of upswings and downswings.

Ellsworth (1956) opposes the Prebisch hypothesis by noting that the net downward movement in the terms of trade of primary products took place in three clearly marked stages that require distinctly different explanations. Looking back a half century later, it must be said that Ellsworth's explanation may seem a bit too ad hoc for the modern economist's liking. Still, here it is: The first period, 1876/80 to 1901/05, can be explained by a sharp decline in transport costs. The significance of the sharp decline in both railway and ocean freight rates between 1876 and 1905 derives from the fact that the price indices 
used for exports of primary producing countries are the c.i.f import prices in British markets, whereas the indices used for their imports are the f.o.b. British export prices. The apparent relative decline in the prices of primary exports at the center is therefore heavily influenced by the significant reduction in freight rates in the three decades that followed the 1870s. It appears certain that a large part of the fall in primary product prices in European markets must therefore be attributed to this cause, in which case, it must be emphasized, their rise in Alexandria, Bangkok, Buenos Aires, Calcutta, Nagasaki and Manila would be explained by the same force (Williamson 2000a). Relative primary product prices stay on a relative level plateau between 1905 and 1913, but for the 1913-1920 period of deterioration Ellsworth agrees with the Prebisch explanation which relies on sticky wages in developed countries. In the years between 1920 and 1929 the deterioration in the terms of trade was due to over-production and an aggravation of over-production by "side effects" stemming from a number of restriction schemes, and to the impact of especially rapid technological advance in manufacturing which was raw-material-saving. As for the last period, the terms of trade of primary-product-producing countries fell from 80 to 63 between 1929 and 1933, and Ellsworth agrees with the Prebisch explanation for this collapse.

Lewis offers a more sophisticated explanation for trends in the price of primary products, although it relates to the Prebisch asymmetric labor market thesis. He illustrates his argument with cane sugar: in spite of well documented productivity growth in cane sugar production, the real wage of cane sugar workers failed to grow in the period 1870-1954 (Lewis 1954: p.183). Lewis infers that wages (and hence real primary product prices) cannot grow in the presence of unlimited supplies of labor at the subsistence wage. As a result, the benefits of technical progress in cane sugar plantation and cane sugar refining accrue to consumers in the industrialized core, not to the workers in the supplying periphery: all the productivity gains in sugar production is passed on to consumers abroad. Elastic labor supplies are therefore critical to Lewis' explanation for the deterioration of primary product prices relative to manufacturers prior to 1940. As Angus Deaton (1999: p. 30) has pointed out, "it is hard to find the data to test such a proposition formally," although current work may supply the answer (Deaton 1999; 
Williamson ongoing).

While empirical models offering explanations for movements in the terms of trade vary, work done prior to 1980 usually abstained from formal modeling. Ronald Findlay changed the character of the theoretical debate when in 1980 he presented a highly stylized dynamic model in which the terms of trade emerged as a mechanism linking output growth in the North (developed countries) and the South (developing countries). Trade is an engine of growth for the South in Findlay's model, but the fuel that drives that engine is generated by the exogenously determined natural growth rate in the North. The natural growth rate in the South is endogenous, depending upon the value of the terms of trade. The steady state terms of trade must be whatever is necessary to make the endogenous growth rate in the South equal to the fixed natural growth rate in the North. As demonstrated in his paper, once and for all improvements in the production function in the North, or increases in its propensity to save, leave the terms of trade unchanged in the long run and increase its per capita income. In the South, on the other hand, these shifts lead to a proportional fall in the long run terms of trade and per capita income, both measured in terms of manufactures.

Findlay stresses that his model provides a different explanation for the declining terms of trade than those of Prebisch and Singer, in that he assumes perfectly competitive markets. Yet, the main feature of the model -- the fact that trade is the engine which eventually equates growth rates between North and South -- certainly makes one wonder about relevance. After all, the North and the South exhibited very different growth rates between 1850 and 1950, when living standard gaps widened dramatically (Pritchett 1997), and, except for East Asia (Bloom and Williamson 1998), they increased still more between 1950 and 1995. Indeed, Prebisch originally claimed that the deteriorating terms of trade was responsible for this gap. Therefore, to construct a model which implies long run per capita income convergence eliminates the very stylized fact to be explained!

William Darity (1990: p. 816) criticizes the Prebisch explanation for the secular decline in the primary product exporter's terms of trade since it is short run in character, rooted in the exercise of 
monopoly power by northern producers. Darity offers a modern alternative. His starting point is Findlay's model. Following Lance Taylor (1981), Darity gives the North a Keynesian cast by dropping the assumption of full employment/natural rate growth and by introducing an independent investment function there. Setting investment equal to savings in the North yields the equilibrium. Under these assumptions, Darity shows how saving propensities and technological conditions in both regions affect the terms of trade. The parameters of the investment function affect the long run terms of trade as well. In order to correspond to the Prebisch-Singer idea that manufactured goods producers exercise monopoly power in pricing, Darity introduces a markup pricing rule in the North. Darity shows that the terms of trade depend on the parameters of the savings and investment function in the North as well as the saving propensity, technical conditions, and the real wage in the South. Changes in the terms of trade are independent of the North's markup, of course, as long as that markup is exogenous and unchanged.

Finally, Darity explores the implications of a financially global economy in which investment does not match savings in every region, that is when capital flows across borders are possible. He then offers an alternative concept for a long view: long-period equilibrium prevails when rates of profit are the same in all regions. This assumption seems more appropriate since it allows the growth rates between North and South to differ, but it then has to deal with the Lucas Paradox (Lucas 1990). A global economy in long-period equilibrium can display persistent divergence in growth rates between North and South -- a dynamic equilibrium with uneven development.

\section{The Empirical Agenda}

We have summarized the major lines of thought that have characterized previous research dealing with the terms of trade of primary-product-producing Third World countries. The overall conclusion seems to be that the terms of trade has deteriorated since 1870 , although exactly how much depends on when, who and what. Since experience has varied across primary products and periods, it surely must 
have varied across the economic histories of different primary-product-producing countries as well. None of the participants in the debate have offered any serious empirical assessment of the impact of terms of trade shocks on the countries that absorbed them.

Our survey highlights what appears to be a gap in this otherwise rich literature. As far as we know, nobody has treated the seven decades following 1870 -- the canonical period of divergence between the center and periphery - as explicit panel data. Countries in the center and periphery exhibit very different experience over that century, and we need to find out why, including the role of terms of trade shocks. Indeed, it is surprising that nobody has explored systematically exactly how these terms of trade shocks - whether deteriorating or improving - impacted the economies thus affected. In addition, while Bloch and Sapsford (1996) have followed Ellsworth's lead in asking what the source of the price shocks in Third World markets was after World War II, nobody has posed the same questions for the years before World War II: how much due to changing world transport costs, to changing mark-ups in the center, or to changing supply and demand in world markets? If the decline in transport costs explains most of the deterioration in the relative price of primary products in OECD markets between 1870 and 1914 or even between 1850 and 1940, then the history that Raoul Prebisch, Hans Singer and W. Arthur Lewis explored can not be very relevant in accounting for post-World War II experience or for-the experience of the $21^{\text {st }}$ century.

The agenda for Third World pre-1940 economic history is vast and urgent, and terms of trade behavior is at the top of the list. The remainder of this paper will work on this agenda by first adding new data which document relative prices in home markets and then second by using this new evidence to explore their impact on countries around the world in the century before 1940, the period about which Prebisch, Singer and Lewis were writing. It is not a large sample (nineteen), and it excludes many of the primary product producers about which Prebisch and Singer were writing, but at least it offers a start towards assessing impact. 


\section{New Evidence: Third World Terms of Trade Trends Before 1940}

In a separate paper, one of the present authors (Williamson 2000a) recently reported terms of trade estimates 1870-1940 for the nineteen sampled countries in Table 1, averaged over half-decades where $1911=100$. While that previous paper constructed terms of trade time series for both the relative price of primary products in home markets $(\mathrm{Pa} / \mathrm{Pm})$ as well as for that of exports relative to imports $(\mathrm{Px} / \mathrm{Pm})$, we only use the net barter terms of trade here $(\mathrm{Px} / \mathrm{Pm})$. All of these estimates were taken from sources which exploited annual price quotes in home markets. In all cases but one, Px/Pm was taken from well-known secondary sources or from some official historical statistics compendium, and the resulting terms of trade series are therefore consistent with trends in the implicit price deflators underlying national accounts. In one case, however, the terms of trade was approximated by the local prices of one key import and one key export (e.g., Siam where the terms of trade was calculated as the price of rice relative to the price of imported textiles). The Appendix describes the sources of the terms of trade data in greater detail.

\section{Who's in the Periphery?}

Since we want to assess the proposition that positive terms of trade shocks had, in the long run, asymmetric effects on economic performance in center and periphery, we need a criteria for the allocation of the 19 countries in our sample between these two categories. The Singer model and its derivatives make the distinction along the lines of primary-product specialization in exports. Recent efforts by Jeffrey Sachs and Andrew Warner (1995b) to explore the post-1971 empirical content of the "resource curse" do the same. Others might find labor scarcity or level of development a better index if the key is that more economically-mature economies can direct windfalls into growth-augmenting activities (like accumulation), while less economically-mature economies waste the windfalls and produce negative externalities. Table 1 reports for the full sample three attributes in the middle of our seven decades, just prior to World War I: labor scarcity, measured here by the 1913 real wage rate of unskilled urban male 
workers (purchasing-power-parity adjusted, and relative to Britain); level of development, measured here by 1913 GDP per capita (in 1990 Geary-Khamis dollars); and primary-product export specialization, measured here as the share of primary-product exports in total exports, averaged over 1905-1914.

Using the unskilled real wage or GDP per capita criteria, it is very clear that the center should include all 12 from Europe and the New World, and Argentina and Uruguay would be among them. The range of both these attributes within the center so defined is modest (with the possible exception of Spain), while the gap between the center and periphery so defined is huge (about $6: 1$ in the case of real wages and about 5:1 in the case of GDP per capita). The periphery would include the rest, and all of them would lie in Asia (defining Asia to include the Middle East). Quite a different conclusion is reached if instead the primary-product specialization criteria is applied. Note, first, that primary products dominated

world trade at this time -- the 1905-1914 average share of primary product exports in total exports being 79 percent for our sample. Note, second, the huge range which this statistic exhibits within Europe (19.9 to 96.7 percent), within the New World (73.3 to 99.9 percent) and even within Asia (67.5 to 99.2). Indeed, in some ways land-scarce East Asia looks more like poor parts of land-scarce Europe than like the rest of Asia. All of this suggests that we explore alternative definitions of center and periphery in what follows, and we will start by distinguishing land-scarce and land-abundant regions, regardless of how rich they are.

[Table 1 about here]

\section{Terms of Trade Evidence}

The new country-specific external terms of trade evidence is summarized at the regional level in Table 2. Four regions are documented in the table: the land abundant New World (unweighted average of Australia, Canada and the USA, sometimes including Argentina and Uruguay, and sometimes not), the 
land abundant Third World (unweighted average of Burma, Egypt, India and Siam (Thailand), ${ }^{8}$ sometimes including Argentina and Uruguay and sometimes not), the land scarce Third World (unweighted average of Japan, Korea and Taiwan), and land scarce Europe (unweighted average of Great Britain, Denmark, Ireland, Sweden, France, Germany and Spain). Thus, there is annual time series evidence documenting seven countries from the Asian periphery, seven from the European center, and five from New World European offshoots. It should be emphasized at the start that, due to lack of data, many tropical primary product producers are omitted from the sample - like Ceylon (tea), Malaysia (rubber), Brazil (coffee, sugar), the Philippines (hemp, sugar), and all of sub-Saharan Africa (cocoa, metals), so we cannot offer the comprehensive coverage that W. Arthur Lewis did in 1978. Thus, our findings must be qualified. Still, the advantage of our approach is that allows an assessment of impact.

[Table 2 about here]

So, what did we expect to find? If commodity price convergence generated by the transport revolution was the only force at work up to World War I, we would have expected the terms of trade $(\mathrm{Px} / \mathrm{Pm})$ to improve for all countries: after all, commodity price convergence serves to raise the price of exportables and lower the price of importables for all trading partners. And if commodity price convergence was the only force at work up to World War I, we would have expected the relative price of agricultural products $(\mathrm{Pa} / \mathrm{Pm})$ to improve for all land-abundant economies which specialized in "agriculture" while we would expect it to deteriorate for all land-scarce economies which specialized in "manufactures." We also would have expected these terms of trade effects to have been bigger in the Asian periphery where the transport revolution seems to have been bigger (Williamson 2000b) and where it was not offset by more protective tariffs. These predictions are qualified by the ceteris paribus "if": after all, there were also world supply and demand forces at work which would have influenced relative price trends.

\footnotetext{
${ }^{8}$ We use the titles Thailand and Siam interchangeably. However, it was the Kingdom of Siam until it became known officially as Thailand after 1949.
} 
Even though these predictions were qualified, they seem to be confirmed: (1) $\mathrm{Px} / \mathrm{Pm}$ rose pretty much everywhere before World War I; (2) Px/Pm rose more in land abundant than in land scarce regions; (3) $\mathrm{Px} / \mathrm{Pm}$ rose more in the land-abundant Asian periphery than in the land-abundant New World; and, although not shown in Table $2, \mathrm{~Pa} / \mathrm{Pm}$ also rose more in the land-abundant periphery. It might be useful to elaborate on the three findings documented in the table.

First, and with only one exception, the terms of trade improved for all trading regions. From the early 1870 s to World War I, the terms of trade rose everywhere. From the early 1890 s to World War I, the terms of trade rose everywhere except in the land-scarce Third World, that is, in East Asia. The Prebisch-Singer assertion simply did not hold for the underdeveloped, primary product exporting periphery prior to World War I, at least for the countries in our sample. However, these results are consistent with Ellsworth's assertion (supported by Spraos) that all of the decline in the relative price of primary products in European markets like London was due to the dramatic fall in transport costs after the 1870s.

Second, the terms of trade rose by more in land-abundant regions than in land-scarce regions. From the early 1890 s to World War I the average changes in $\mathrm{Px} / \mathrm{Pm}$ were 17.6 percent vs -3.9 percent in land-abundant and land-scarce countries, respectively. From the early 1870 s to World War I the figures were 37.1 vs 3.4 percent. Clearly, the land-abundant periphery was confronted with far more favorable price shocks prior to World War I than was the land-scarce and industrializing center. Once again, the Prebisch-Singer assertion simply did not hold for the underdeveloped, primary product exporting periphery, at least prior to World War I, and at least for the countries in our sample.

Third, the terms of trade rose by more in the land-abundant Third World than in the landabundant New World. How one categorizes the Southern Cone matters at this point. With Argentina and Uruguay allocated to the Third World periphery group, $\mathrm{Px} / \mathrm{Pm}$ rose by 48.5 percent between the early 1870s and World War I, compared to 25.7 percent in the New World. With Argentina and Uruguay again allocated to the Third World periphery, $\mathrm{Px} / \mathrm{Pm}$ rose by 21.1 percent between the early 1890 s and World 
War I, compared to 10.7 percent in the New World. To summarize, commodity price convergence up to World War I caused a predictable convergence in relative prices between land-scarce and land-abundant countries the world around, and the resulting terms of trade boom in the land-abundant parts of Latin America, the eastern Mediterranean and Asia was considerably bigger than in North America and Australasia.

A dramatic regime switch took place for relative price trends after World War I, partly because the transport revolution slowed down, partly because of the retreat towards autarky in what we now call the OECD and in Latin America, and partly due to other forces. The first two forces would have served to cause a slowdown or perhaps even a reversal in commodity price convergence. Furthermore, the retardation in world growth ${ }^{9}$ must also have twisted the fundamentals underlying all commodity markets in ways that might account for the regime switch. Thus, $\mathrm{Pa} / \mathrm{Pm}$ collapsed in all regions after World War $\mathrm{I}$, although it collapsed by more in land-abundant regions (Williamson 2000a), two events which provoked Raoul Prebisch, Hans Singer, Ragnar Nurkse, Gunnar Myrdal and W. Arthur Lewis to infer that the primary product boom was over and that an epoch of deterioration had set in, an event that they thought warranted the pro-industry intervention, a policy stance that stuck until the move back towards openness started in the 1970s. Furthermore, Table 2 shows just how spectacular the terms of trade regime switch was for the land-abundant parts of the Third World around World War I. While the Px/Pm trend rose in land-scarce Europe by 10.2 percentage points (from 0.9 percent between the early 1890 s and World War I to 11.1 percent after), and while its fall in land-scarce East Asia was a relatively modest 4.7 percentage points $(-18.4$ to -23.1 percent), it fell by 12.8 percentage points in the land-abundant New World (with Argentina and Uruguay), and it fell by an enormous 24.1 percentage points in the land-abundant Third World (without Argentina and Uruguay).

If Prebisch and Singer were looking for evidence of terms of trade deterioration around the

9 Maddison (1995: Table 3-1, p. 60) reports "world" GDP per annum growth (in percent) of: 1820-1870, 1 ; 1870-1913, 2.1; 1913-1950, 1.9; and 1950-1973, 4.9. 
periphery, it appears that the place for them to have looked should have been after World War I, not before. These new revisionist facts summarized in Table 2 are plotted in Figures 4-6 for seven Middle Eastern and Asian countries. The terms of trade rose for late $19^{\text {th }}$ century Japan, Korea and Thailand (Figure 4), and then fell over the first half of the $20^{\text {th }}$ century (with a modest revival in the 1920 s before the crash). The terms of trade rose for Burma and was stable for Taiwan up to World War I (Figure 5), fell sharply during and after the war, and then was fairly stable (at a lower level) during the interwar years. The terms of trade for India rose from the 1870s to World War I, it rose for Egypt from the 1890s to World War I (Figure 6), and both fell thereafter.

[Figures 4-6 about here]

\section{The Impact of Quasi-Permanent Price Shocks}

\section{Motivation}

We have now established what really happened to the terms of trade in the primary-producing periphery before 1940. Furthermore, we have seen that these relative price shocks persisted for very long periods, suggesting that they can be treated as quasi-permanent.

This "quasi-permanent" label is important, since it serves to distinguish our agenda from a literature that has, instead, focused on instability and short term price shocks. For example, an important paper by William Easterly, Michael Kremer, Lant Pritchett and Lawrence Summers (1993) showed that terms of trade shocks can explain much of the highly unstable growth rates observed in the late $20^{\text {th }}$ century. The African literature offers another example. Africa's terms of trade deteriorated significantly after the early 1980 s, perhaps by as much as 36 percent, an unfortunate price shock that has been estimated to have cost Africa something like 0.7 percentage points in its growth rate compared with other Third World countries (Collier and Gunning 1999: p. 73; Deaton 1999: p. 37). But this streak of bad luck did not persist since previous price levels were recovered late in the 1990s (Deaton 1999: p. 32). Andrew 
Warner (1992) has documented the impact of bad terms of trade shocks on Mexican growth and debt defaults in the 1980s, but recovery followed. There is also an old and well-developed literature on the impact of the bad price shocks associated with the Great Depression on, especially, Latin America (Kindleberger 1973; Maddison 1985; Diaz-Alejandro 1984). Thus, there is a well developed literature that explores the impact of short-term price shocks on late $20^{\text {th }}$ century economies. But nowhere is there a systematic attempt to assess the impact of external price shocks on economic performance in the long run.

The pre-1940 experience offers two epochs of very long duration, one of primary product relative price boom prior to World War I, followed by one of slump. These epochs were much longer than those of the late $20^{\text {th }}$ century reviewed in the previous paragraph. So, what was the impact of these quasipermanent price shocks? There is certainly no shortage of opinion on this issue, but empirically-informed answers are exceedingly scarce. While we know quite a bit about the impact of bad terms of trade shocks on late $20^{\text {th }}$ century, we know almost nothing about the pre-1940 experience. Furthermore, any assessment will have trouble decomposing two potentially offsetting forces. Over the short run, positive terms of trade shocks will always (ceteris paribus) raise GDP, and the empirical issue is only how much. If the export sector was a third of GDP (a large share by the standards of that time), and if the terms of trade improved by 10 percent over a decade (a pretty big, quasi-permanent relative price shock), then ceteris paribus annual GDP growth would have been raised by about 0.3 percentage points, not a very big bang if the country was growing at 2 to 3 percent per annum. In any case, over the long run a positive terms of trade shock in primary-product-producing countries will reinforce comparative advantage, suck resources into the export sector from other activities, and cause de-industrialization. To the extent that industrialization is the prime carrier of capital-deepening and technological change, then Hans Singer was right to assert that positive external price shocks for primary producers will lower growth rates in the long run. The apparent regime switch from the de-industrialization experience around the periphery in the $19^{\text {th }}$ century to the re-industrialization experience in the $20^{\text {th }}$ century - long before the $1950 \mathrm{~s}$ - needs special treatment, but a deteriorating terms of trade of primary products might be part of the explanation. This 
paper does not attempt to decompose the short run and long run components of these terms of trade shocks, although ongoing research by one of the authors hopes to do so. ${ }^{10}$ Instead, we only ask here whether the combined sum of the competing and offsetting short and long run terms of trade effects around the periphery were on net positive or negative, and whether they were different than those in the center where the short run and long run effects were complementary and mutually supporting.

\section{A Simple Conditional Convergence (or Divergence) Model}

The empirical growth model we use here is in the modern tradition set by Robert Barro, Jeffrey Sachs and many others (Barro and Sala-i-Matin 1995; Barro 1997; Mankiw, Romer and Weil 1992; Sachs and Warner 1995a; Bloom and Williamson 1998). Yet we face far more serious data constraints than do these scholars when they work with the late $20^{\text {th }}$ century, the Penn World Tables, and other public use samples from the UN and IBRD. Due to the absence of data describing most plausible explanatory variables across most of our panel, our conditional convergence (or divergence) growth model will have very few of the conditionals present in most modern models - like public investment, demographic. burdens, the quality of government, or a property rights tradition, although we will have a far better measure of openness then do most modern models. For every model estimated in the tables that follow, the unit of observation is country per annum growth over a decade, a period which we think is long enough for "quasi-permanent" prices shocks to have their long term impact on growth. There are 19 countries in the panel, and if all of them were documented comprehensively each country would offer 7 observations, the decade of the 1870 s through the decade of the 1930s. The maximum of 133 observations is, alas, never achieved, our largest sample being instead 108 (and the smallest, 78).

In growth rates, there are two dependent variables explored in what follows: Angus Maddison's GDP per capita estimates in 1990 Geary-Khamis dollars; and Jeffrey Williamson's purchasing-power-

\footnotetext{
${ }^{10}$ See footnote 3 .
} 
parity adjusted real wage rates for urban unskilled workers. It makes sense to see how robust the results are when moving between these two independently-estimated data sets. Furthermore, there are sound theoretical reasons to expect somewhat different results for each. After all, trade theorists since Heckscher and Ohlin have known that positive external price shocks in primary-product-exporting countries favor some, like landlords, more than others, like unskilled workers, while in manufactures-exporting countries it is the other way around (Wood 1995; Williamson 2000a; Lindert and Williamson 2000). Thus, the aggregate effect on GDP per capita may not be the same as on the real wage, nor need it be the same for center and periphery. It should be useful to sort these differences out.

The explanatory variables are initial real wage or GDP per capita at the start of the decade, the growth in the terms of trade over the same decade, and the growth in the land-labor ratio over the same decade. If there was catching up in this sample of 19 countries between 1870 and 1940 , then the coefficient on these initial values would be negative, rich countries growing more slowly. Previous research suggests that we should expect evidence of catching up between 1870 and World War I in a center that includes Europe and the New World, but that evidence of within-center convergence should evaporate during the troubled interwar years of autarky (Williamson 1996, 1998; O'Rourke and Williamson 1999, Chp. 2). However, we should expect dramatic divergence in a world sample that includes the periphery (DeLong 1988; Pritchett 1997). We use dummy variables in our growth regressions to capture differences between the periphery) and the center. Initially, we define the center and periphery according to the labor scarcity and level of development criteria in Table 1 (periphery $=\mathrm{D} 1=$ Burma, Egypt, India, Japan, Korea, Taiwan, Thailand; center = D2 = Argentina, Australia, Canada, Denmark, France, Germany, Great Britain, Ireland, Spain, Sweden, USA, Uruguay), although we will experiment with alternative definitions to check the robustness of the results.

The terms of trade effect is explored in the conditional growth model by itself (a larger sample) and also interacted with the export-GDP ratio, the latter added to capture the size of the sector (a smaller sample). Finally, while we certainly would be delighted to add human and physical capital deepening 
variables to the analysis, they do not exist for the vast majority of these countries prior to 1940; as a consequence, we are prepared for low $R^{2}$, but insist on high t-statistics.

\section{Estimation Problems and Solutions}

Francesco Caselli, Gerardo Esquivel and Fernando Lefort (1996) offer a critical survey which exposes some econometric problems embedded in the recent empirical growth literature. Using their terminology, the typical cross-country study is built on some estimating equation nested in the following general specification:

$$
\ln \left(Y_{i, t}\right)-\ln \left(Y_{i, t-\tau}\right)=\beta \ln \left(Y_{i, t-\tau}\right)+W_{i, t-\tau} \delta+\eta_{i}+\xi_{t}+\varepsilon_{i, t}
$$

where $Y_{i, t}$ is the per capita GDP in country $i, W_{i, t}$ is a row vector of determinants of economic growth,

$\eta_{i}$ is a country-specific effect, $\xi_{t}$ is a period specific constant, and $\varepsilon_{i, t}$ is an error term. A negative coefficient on the GDP per capita variable is, of course, consistent with the neoclassical prediction that countries relatively close to their steady state output level will experience a growth slowdown. The variables in $W_{i, t}$ and the individual effect $\eta_{i}$ are proxies for this long-run level on which the country is converging, and the time dummy, $\xi_{t}$, is expected to capture global shocks affecting aggregate production function across the board.

Equation (1) can be rewritten as

$$
y_{i, t}=\widetilde{\beta}_{i, t-\tau}+W_{i, t-\tau} \delta+\eta_{i}+\xi_{t}+\varepsilon_{i, t}
$$

$$
\text { where } \widetilde{\beta}=1+\beta \text { and } y_{i, t}=\ln \left(Y_{i, t}\right)
$$


Equation (2) makes it clear that estimating (1) is equivalent to estimating a dynamic equation with a lagged dependent variable on the right-hand side. Caselli et al. (1996: pp. 366-7) claim that the previous literature ignores significant econometric problems. They criticize the cross section regression literature (Barro 1991; Mankiw, Romer and Weil 1992; Barro and Sala-i-Martin 1992; and many others) for its treatment of the country specific effect. Since it is correlated with the other right-hand side variables in

equation (2), these studies get inconsistent estimators. Furthermore, the elements in $W_{i, t}$ are likely to be endogenous (e.g., the rate of investment in physical capital is determined simultaneously with the rate of growth). Caselli et al. suggest that panel data can help solve some of these problems. Thus, Barro and Sala-i-Martin (1995: chp. 12) attack the endogeneity issue by splitting their panel data into two subperiods (1965-1975 and 1975-1985).

Since additional econometric problems remain, Caselli et al. devise a GMM estimator that takes into account both endogeneity and correlated effects, but it is consistent only when using a large sample. Our samples are too small for GMM estimation to teach us much. Thus, we do not use it here. However, the Caselli et al. critique does persuade us to reject fixed effects estimation in favor of OLS, especially given more degrees of freedom in the latter case. While OLS may appear to be only the lesser of the econometric evils, we do the best we can by using Robust OLS (that is, the standard errors are corrected for heteroskedasticity). Finally, we also estimated a model using the lagged dependent variables as instruments, but since the Robust OLS results were only trivially changed by doing so (and almost not at all for the terms of trade variables), we do not report the instrumental variable results here.

\section{Price Shocks, Endowment Changes, Catching Up, Falling Behind}

The key findings are presented in Table 3A, where the left-hand panel reports the regression model with real wage growth as the dependent variable (and the initial real wage among the independent variables), and the right-hand panel reports the regression with GDP per capita as the dependent variable 
(and initial GDP per capita among the independent variables). The $R^{2}$ is, as predicted, not large - ranging between 0.19 and 0.34 -- but the rest of the results are quite good. ${ }^{11}$ Four key findings deserve emphasis.

[Table $3 \mathrm{~A}$ about here]

First: There was convergence in the center, although it was much stronger for the unskilled real wage $(-1.161, t=2.048$, on $\log$ initial wage $)$ than it was for GDP per capita $(-0.708, t=1.846$, on $\log$ initial GDP per capita). This result confirms earlier work (Williamson 1996, 1998; O’Rourke and Williamson 1999; Lindert and Williamson 2000), and it is consistent with two kinds of theory: it is consistent with the Heckscher-Ohlin model which argues that factor price convergence should be more dramatic than any aggregation of factor prices (like national income or GDP); and it is consistent with empirical growth theory which argues that most of average real earnings growth can be attributed to increased human capital deepening and movements up the skill ladder (as opposed to higher rungs, or wages, everywhere on the ladder), movements that were much more pronounced in the center than in the periphery (Easterlin 1981; Clemens and Williamson 2000). Furthermore, although Table 3A does not report the result, GDP per capita convergence in the center is estimated here to have been much stronger prior to $1920(-0.995, t=2.085$, on $\log$ initial GDP per capita), implying that the much weaker GDP per capita convergence results for the full period up to 1940 (to repeat: $-0.708, t=1.846$ ) is due to a convergence slowdown or even to a switch to divergence in the interwar years. ${ }^{12}$

Second: The periphery (countries denoted by the dummy D1) was not involved in that convergence. Indeed, over these seven decades there was powerful GDP per capita divergence. Not only

\footnotetext{
11 Tables 3A, 3B and 4 are all estimated for the full period 1870-1940. These regressions were also estimated separately for the pre-World War I period (using both 1870-1910 and 1870-1920), and the results were not significantly different from those for the full period. Thus, while there may have been a regime switch between pre-World War I and post-World War I trends in what we take here to have been exogenous variables, like changes in the terms of trade, there was no significant change in the way our sampled economies responded to changes in those variables, especially the terms of trade.

${ }_{12}$ This cannot be estimated directly here since the time period 1920-1940 is too short and thus there are too few degrees of freedom. The indirect inference is clear enough, however.
} 
was this true within the periphery $(-0.708+3.045=2.337)$ - East Asia pulls away a bit from the rest but, more importantly, it was manifested by an enormous gap in average performance between center and periphery (the coefficient of $\mathrm{D} 1=-21.774, \mathrm{t}=4.071$ ), the kind of performance that warranted Lant Pritchett (1997) to call it "divergence, big time." Note, however, that what was true of GDP per capita was not true of real wage rates for unskilled workers: while statistically insignificant, the coefficient on D1 is positive in the left-hand panel $(0.209, \mathrm{t}=0.042)$, not negative. Thus, while the growth in unskilled labor's living standards did not significantly lag behind in the periphery, growth in the average wage and the average living standards in the periphery did fall behind. The reason, of course, is that skill-deepening, capital-deepening and growth in the value marginal product of skills, capital and other modern inputs all lagged behind, and by a lot (as revealed by that big negative coefficient reported on D1 in the right-hand panel).

Third: While land-labor ratio changes seem to have mattered to growth in the center, they did not matter very much $(0.119, t=0.748$, left-hand panel; $0.142, t=2.865$, right-hand panel). After all, most of the countries in the center underwent increased pressure on the land -- that is, falling land-labor ratios (LL) times those positive coefficients translate into a drag on growth -- and thus they had to find other ways to offset diminishing returns. Obviously, the accumulation of physical and human capital mattered far more to economic growth in the center. As for the periphery, and paradoxically, the land-labor ratio seems to have mattered even less: the positive coefficient on LL tends to evaporate when the interaction with D1 is added, and in both the real wage and the GDP per capita growth regressions. We say "tends to" since in neither case is the estimated coefficient significantly different from zero $(t=0.806$ and 0.664$)$. We do not have an explanation for this weakly suggested asymmetry (although the suggestion is stronger in Table 3B sample, where $t=2.984$ in the left-hand panel), although we recognize that Arthur Lewis 
$(1952,1954)$ has argued that the causality went from output growth to (elastic) labor supply response, not the other way around. ${ }^{13}$

Fourth and finally: An improving terms of trade augmented growth in the center: that is, the coefficient on tot (terms of trade growth over the decade) is $0.314(t=4.478)$ in the wage growth regression and $0.213(t=3.101)$ in the GDP per capita regression. Furthermore, and to repeat, these results seem to be quite robust since they hardly change at all when these equations are re-estimated using the lagged dependent variable as an instrument, and they are also confirmed with the Table 3B sample, as we shall see in a moment. However, what was true of the center was not true of the periphery. These growth-augmenting effects from positive terms of trade shocks in the center disappear in the periphery: the negative (and significant) coefficients from the interaction between tot and D1 overwhelm those for tot alone in both regressions $(0.314-0.393=-0.079$ in the left-hand panel, and $0.213-0.326=-0.113$ in the right-hand panel). We interpret these findings in the following way: for the periphery, the short-run gain from an improving terms of trade was overwhelmed by a long-run loss attributed to deindustrialization; for the center, the short-run gain was reinforced by a long-run gain attributed to industrialization.

As we have already indicated, Table 3B reports the same regressions as Table $3 \mathrm{~A}$, except the former uses a smaller sample to be consistent with that of Table 4. There is little difference between the results with the two samples, the Table 3B sample excluding, because of lack of Export/GDP data, Burma, Denmark, Egypt, Ireland, Sweden and Unuguay. The similarity between the two tables is especially apparent for the tot variables, suggesting that our terms of trade inferences are robust with regards to country sample.

[Table 3B about here]

\footnotetext{
${ }^{13}$ Ronald Findlay (1995), supporting earlier work by Hla Myint $(1958,1964)$ and others, has argued that the same was true of land supply. In two other papers, one of the present authors tries to unravel this causality problem (Williamson $2000 \mathrm{a}$, ongoing).
} 
Table 4 replaces tot with the product of tot and dxy, where the latter is the export share in GDP, here taken as the average (fixed weight) share within the periods for which the growth rates are calculated. Thus, Table 4 uses relative price shocks which are sector-size adjusted while those in Table 3B do not make the adjustment. Once again, there is very little difference between the two tables: the coefficients on the non-price variables are very similar, and the signs on the price variable are identical. The magnitudes on the terms of trade variables are, of course, different, but they imply the same conclusion regarding differential impact on center versus periphery: for the same price shock, and for the same sized export sector, the impact of a positive terms of trade shock is unambiguously positive for the center but unambiguously negative for the periphery. In short, the results are robust to sample and to the terms of trade specification.

[Table 4 about here]

\section{Does It Matter Who Is in the Periphery?}

Table 1 suggests that we explore whether the asymmetric terms of trade effects are sensitive to alternative definitions of periphery membership. We have tried defining membership in four ways: Periphery I, the allocation used thus far = Burma, Egypt, India, Japan, Korea, Siam, Taiwan; Periphery II $=$ Periphery I + Argentina and Uruguay; Periphery III = Periphery II + Australia and Canada; and Periphery IV = Periphery III + United States. The asymmetric terms of trade impact on GDP per capita growth is robust across the definitions of periphery, at least in this sample:

$\begin{array}{lcc} & \text { tot } & \text { tot x D1 } \\ \text { Periphery I } & 0.213(3.101) & -0.326(4.061) \\ \text { Periphery II } & 0.204(2.674) & -0.252(2.651) \\ \text { Periphery III } & 0.171(2.476) & -0.196(2.190) \\ \text { Periphery IV } & 0.171(2.464) & -0.192(2.131)\end{array}$




\section{Did Price Shocks Impact Growth or Vice Versa?}

There is, of course, another literature that recognizes the asymmetry between center and periphery, but proposes the reverse causality. Could it be that productivity advance in a primary producer was met with falling prices along a price-inelastic demand curve, while the opposite was true of an industrial goods producer facing a more price-elastic demand curve? Alternatively, could it be that, because of elastic labor supply in the periphery, productivity gains there caused a terms of trade decline? Given the evidence in Table 2 that documents ubiquitous and large terms of trade improvements in the periphery during the globalization boom up to World War 1, "immizerising growth" (e.g. Bhagwati 1958) seems like an unlikely possibility at least in our sample. Furthermore, the sticky-wage-in-the-center premise which Singer and the modern Keynesian models invoke simply cannot be supported with $19^{\text {th }}$ century evidence. Still, while we think reverse causality in most of the pre-1940 period is unlikely, the economics originating in the writings of Singer and, especially, Lewis (1954: see above) needs an explicit assessment. Unfortunately, this sample is too small to perform that test properly, so it will have to await future research.

\section{Did It Matter Much?}

The final question is this: How much of the growth in GDP per capita or in real wages can be assigned to terms of trade changes over these seventy years? Was it big or small? Was it different in the center compared with the periphery? Was it different in the pre-war compared with the interwar decades? The results are summarized in Tables 5A (1870-1914) and 5B (1914-1940). Both tables use the terms of trade shock unadjusted by the share of exports in GDP since were we to make the adjustment we would lose six countries that do not have the necessary trade share data (Burma, Denmark, Egypt, Ireland, 
Sweden, Uruguay). The gain is worth it, and the loss is modest since the unreported but calculated exportshare-adjusted terms of trade shock yields results very similar to those in Tables $5 \mathrm{~A}$ and $5 \mathrm{~B} .{ }^{14}$

The key findings can be found in column (4) of the tables where we report the share of observed GDP per capita growth accounted for by these exogenous terms of trade shocks. First, the shocks typically had a negative impact on growth performance in the periphery up to World War I. The exceptions to this rule were Burma and Taiwan. The results for the interwar were mixed. Second, the shocks typically had a positive impact on growth performance in the center up to World War I, but there were more exceptions to this rule: they didn't matter hardly at all to France throughout the whole period or to Ireland during the interwar years; they were negative for Australia throughout; and they were negative for Germany and Spain prior to 1914 and for Canada during the interwar. Third, where the shares were big, typically the overall growth performance was very poor. This was true of every case in the periphery where the terms of trade shocks accounted for more than a fifth of the observed growth, except, perhaps, Korea before World War I, although the pre-war Korean GDP per capita growth of 0.822 per annum can hardly be called outstanding. This was also true of every case in the center where the shocks accounted for significantly more than a fifth of growth, except for Germany during the interwar years. For example, the shares are a fifth or bigger during the interwar for Australia, Canada, and Spain, but none of these three countries recorded per capita GDP growth rates greater than a dismal 0.34 . In short, long run terms of trade shocks typically didn't matter much, whether it was positive or negative, and whether it was center or periphery.

[Tables 5A and Table 5B about here]

\footnotetext{
${ }^{14}$ Here are a few comparative examples of the column (4) calculation of the adjusted and unadjusted terms of trade impact of GDP per capita growth 1870-1914: India -4.8 vs -10.5 ; Taiwan 1.0 vs 3.4; Thailand -12.3 vs -18.3 ; Australia -9.9 vs -6.5 ; Canada 13.9 vs 9.0 ; and Spain -6.0 vs -6.6 .
} 


\section{Concluding Remarks}

Raoul Prebisch was right about the terms of trade between 1870 and World War I: these globalization-induced relative price shocks tended to diminish growth performance in the periphery. But he was right for the wrong reasons. The terms of trade did not deteriorate in the periphery sampled in this paper. On the contrary, it improved up to World War I, and, furthermore, it improved by more than it did in the center. However, and consistent with Hans Singer's prediction, these positive relative price shocks had an asymmetric impact in center and periphery, boosting growth in the center and suppressing it in the periphery. Why the asymmetry? Until future research can confirm this plausible link, we simply assume that the asymmetry will be explained by one of the competing hypotheses which now dominate the literature. Here is one that dates at least from as far back as Singer: the long run impact of these relative price shocks reinforced industrial comparative advantage in the center -- favoring the sector which carried growth, while it reinforced primary product comparative advantage in the periphery - penalizing the sector which carried growth. Here is another that has earned the label "resource curse": the long run. impact of these relative price shocks caused capital flight and rent seeking in the primary producers, both of which diminished long run growth potential. Furthermore, we think the evidence, at least in our limited sample, points to causality that runs from exogenous price shocks (driven mainly by world transport events) to economic performance, not vice versa.

Still, the estimates here suggest that the net impact of these terms of trade shocks was very small. In the pre-war period, the share "explained" by terms of trade shocks was typically less than a fifth of the observed GDP per capita growth rate. Where the share explained was more, usually it was due to the fact that the growth performance was poor. Out of thirty-four possibilities, the terms of trade shock really only mattered for one periphery country-period (pre-1914 Korea, -37 percent) and for three center countryperiods (interwar Germany 25.2 percent, Great Britain 34.8 percent, and the United States 18.8 percent). 
It appears that the great terms of trade debate was about an event which was pretty minor for most participants in the center and the periphery. The fundamentals inside these countries mattered most to growth, just as they do today. 


\section{References}

Ardeni, P. G. and B. Wright (1992). "The Prebisch-Singer Hypothesis: A Reappraisal Independent of Stationarity Hypotheses," Economic Journal 102: 803-12.

Bairoch, P. (1975). The Economic Development of the Third World Since 1900 (London: Methuen).

Baldwin, R. S. (1955). "Secular Movements in the Terms of Trade," American Economic Review 45: 259-69.

Barro, R. J. (1991). "Economic Growth in a Cross-Section of Countries." Quarterly Journal of Economics 106: 407-443.

Barro, R. J. (1997). Determinants of Economic Growth (Cambridge, Mass.: MIT Press).

Barro, R. J. and X. Sala-i-Matin (1995). Economic Growth (New York: McGraw Hill).

Bhagwati, J. (1958). "Immiserizing Growth: A Geometrical Note," Review of Economic Studies 25 (June): 201-5.

Bleany, M. and D. Greenway (1990). "Long-Run Trends in the Relative Price of Primary Commodities and in the Terms of Trade of Less Developed Countries - A Further Analysis," Credit Discussion Paper No. 90/9, University of Nottingham.

Bleany, M. and D. Greenway (1993). "Long-Run Trends in the Relative Price of Primary Commodities and in the Terms of Trade of Developing Countries," Oxford Economic Papers 45: 349-63.

Bloch, H. and D. Sapsford (1996). "Trends in the International Terms of Trade Between Primary Producers and Manufacturers," Journal of International Development 8: 53-67.

Bloch, H. and D. Sapsford (1997). "Some Estimates of Prebisch and Singer Effects on the Terms of Trade between Primary Producers and Manufacturers," World Development 25: 1873-84.

Bloch, H. and D. Sapsford (2000). "Whither the Terms of Trade? An Elaboration of the Prebisch-Singer Hypothesis," Cambridge Journal of Economics 24 (July 2000): 461-81.

Bloom, D. and J. G. Williamson (1998). "Demographic Transitions and Economic Miracles in Emerging 
Asia," World Bank Economic Review 12, 3 (September): 419-55.

Caselli, F., G. Esquivel and F. Lefort (1996). “Reopening the Convergence Debate: A New Look at Cross-Country Growth Empirics," Journal of Economic Growth 1:363-89.

Clemens, M. A. and J. G. Williamson (2000). "Where Did British Foreign Capital Go? Fundamentals, Failures and the Lucas Paradox," NBER Working Paper 8028, National Bureau of Economic Research, Cambridge, Mass. (December).

Collier, P. and J. W. Gunning (1999). “Why Has Africa Grown Slowly?” Journal of Economic Perspectives 13: 3-22.

Cuddington, J. T. (1992). "Long-run Trends in 26 Primary Commodity Prices," Journal of Development Economics 39: 207-27.

Cuddington, J. T. and C. M. Urzua (1989). "Trends and Cycles in the Net Barter Terms of Trade: A New Approach," Economic Journal 99: 426-42.

Darity, W. (1990). "The Fundamental Determinants of the Terms of Trade Reconsidered: Long-Run and Long-Period Equilibrium," American Economic Review 80: 816-27.

DeLong, J. B. (1988). "Productivity Growth, Convergence and Welfare: A Long-Run Look 1870-1980," American Economic Review 78: 1138-54.

Deaton, A. (1999). "Commodity Prices and Growth in Africa," Journal of Economic Perspectives 13: 23 40.

Diakosavvas, D. and P. L. Scandizzo (1991). "Trends in the Terms of Trade of Primary Commodities, 1900-1982: The Controversy and Its Origin," Economic Development and Cultural Change 39: 231-64.

Diaz-Alejandro, C. F. (1983). "Stories of the 1930s for the 1980s," in P. Armella, et al. (eds.), Financial Policies and the World Capital Market: The Problem of Latin America (Chicago: University of Chicago Press). 
Diaz-Alejandro, C. F. (1984). "Latin America in the 1930s," in R. Thorp (ed.), Latin America in the 1930s (New York: Macmillan): 17-49.

Easterly, W.; M. Kremer; L. Pritchett; and L. H. Summers (1993). “Good Policy or Good Luck? Country Growth Performance and Temporary Shocks," Journal of Monetary Economics 32: 459-83.

Easterlin, R. A. (1981). "Why Isn't the Whole World Developed?" Journal of Economic History 41: 1-19.

Ellsworth, P. T. (1956). "The Terms of Trade Between Primary Producing and Industrial Countries," Inter-American Economic Affairs 10: 47-65.

Findlay, R. (1980). "The Terms of Trade and Equilibrium Growth in the World Economy," American Economic Review 70: 291-9.

Findlay, R. (1995). Factor Proportions, Trade, and Growth (Cambridge, Mass.: MIT Press).

Ford, A. G. (1955). "Export Price Indices for the Argentine Republic 1881-1914," Inter-American Economic Affairs 9, 2: 42-54.

Frank, I. (1976). "Toward a New Framework for International Commodity Policy," Finance and Development 13: 17-20.

Grilli, E. and M. C. Yang (1988). "Primary Commodity Prices, Manufactured Goods Prices and the Terms of Trade of Developing Countries: What the Long-Run Shows," World Bank Economic Review 2: $1-47$.

Haberler, G. (1959). International Trade and Economic Development (Cairo: National Bank of Egypt).

Hyde, G. L. (1963). "A Critique of the Prebisch Thesis," Economia Internazionale 16: 463-87.

Instituto de Estudios Economicos sobre la Realidad Argentina y Latinoamericana (1986), "Estadisticas de la evolucion economica de Argentina, 1913-1984," Estudios 9, 39 (July/September):

Isserlis, L. (1938). "Tramp Shipping Cargoes and Freights," Journal of Royal Statistical Society 101: $53-$ 146.

Johnson, H. G. (1967). Economic Policies Toward Less Developed Countries (Washington, D. C.: Brookings Institution). 
Kenwood, A. G. and A. L. Lougheed (1971). The Growth of the International Economy (London: Allen and Unwin).

Kindleberger, C. P. (1956). Terms of Trade: A European Case Study (New York: John Wiley).

Kindleberger, C. P. (1958). "The Terms of Trade and Economic Development," Review of Economics and Statistics 40 (Supplement): 72-85.

Kindleberger, C. P. (1973). The World in Depression 1929-1939 (Berkeley, CA.: University of California Press).

Krueger, A. O. (1974). "The Political Economy of the Rent-Seeking Society," American Economic Review 64 (June): 291-323.

League of Nations (1945). Industrialization and Foreign Trade (Geneva).

Lewis, W. A. (1952). "World Production, Prices and Trade, 1870-1960," Manchester School of Economic and Social Studies 20: 105-33.

Lewis, W. A. (1954). "Economic Development with Unlimited Supplies of Labour," The Manchester School of Economics and Social Studies 2: 139-91.

Lewis, W. A. (1978). Growth and Fluctuations 1870-1913 (London: Allen and Unwin).

Lindert, P. H. and J. G. Williamson (2000). "Does Globalization Make the World More Unequal?" Paper presented at the Globalization in Historical Perspective pre-conference, National Bureau of Economic Research, Cambridge, Mass. (November 16, 2000).

Lipsey, R. E. (1963). Price and Quantity Trends in the Foreign Trade of United States (Princeton: Princeton University Press).

Lipsey, R. E. (1994). "Quality Change and Other Influences on Measures of Export Prices of Manufactured Goods," World Bank Policy Research Working Paper No. 1348, Washington, D.C.

Lucas, R. (1990). “Why Doesn't Capital Flow from Rich to Poor Countries?” American Economic Review 80 (May): 92-6.

Macbean, A. and V. N. Balasubramanyam (1978). Meeting the Third World Challenge (London: 
Macmillan, $2^{\text {nd }}$ ed.).

Maddison, A. (1985). Two Crises: Latin America and Asia 1920-1938 and 1973-1983 (Paris: OECD).

Maddison, A. (1995). Monitoring the World Economy 1820-1992 (Paris: OECD Development Centre Studies).

Maizels, A. (1963). Industrial Growth and World Trade. (Cambridge University Press.)

Mankiw, N. G., D. Romer and D. N. Weil (1992). "A Contribution to the Empirics of Economic Growth," Quarterly Journal of Economics 107: 407-37.

Meier, G. M. (1958). "International Trade and International Inequality," Oxford Economic Papers 10: 277-89.

Meier, G. M. (1963). International Trade and Development (New York: Harper and Row).

Meier, G. M. and R. E. Baldwin (1957). Economic Development: Theory, History, Policy (New York: John Wiley).

Morgan, T. (1959-60). "The Long-Run Terms of Trade between Agriculture and Manufacturing," Economic Development and Cultural Change 8: 1-23

Morgan, T. (1963). "Trends in Terms of Trade and Their Repercussions on Primary Producers," in R. Harrod and D. Hague (eds.), International Trade Theory in a Developing World (London: Macmillan): 52-72.

Myint, H. (1958). "The 'Classical Theory' of International Trade and Under-developed Countries," Economic Journal 68: 317-37.

Myint, H. (1964). The Economics of Developing Countries (London: Hutchinson).

O’Rourke, K. H. and J. G. Williamson (1999). Globalization and History (Cambridge, Mass.: MIT Press). Powell, A. (1991). "Commodity and Developing Country Terms of Trade: What Does the Long Run Show?" Economic Journal 95: 781-8.

Prebisch, R. (1950). The Economic Development of Latin American and Its Principal Problems (New York). Reprinted in Economic Bulletin for Latin America 7 (1962): 1-22. 
Pritchett, L. (1997). "Divergence, Big Time," Journal of Economic Perspectives 11, 3 (Summer): 3-17. Ray, G. F. (1977). "The Real Price of Primary Products," National Institute Economic Review 81: 72-6. Sachs, J. D. and A. M. Warner (1995a). “Economic Reform and the Process of Global Integration," Brookings Papers on Economic Activity 1: pp. 1-118.

Sachs, J. D. and A. M. Warner (1995b). "Natural Resource Abundance and Economic Growth," NBER Working Paper 5398, National Bureau of Economic Research, Cambridge, Mass. (December). Sapsford, D. (1990). "Primary Product Prices and the Terms of Trade," Economic Journal 95: 342-56. Sapsford, D. and V. N. Balasubramanyam (1994). "The Long-Run Behaviour of the Relative Price of Primary Commodities: Statistical Evidence and Policy Implications," World Development 22: 1737-45.

Sarkar, P. and H. W. Singer (1991). "Manufactured Exports of Developing Countries and Their Terms of Trade Since 1965," World Development 19: 333-40.

Schloss, H. H. (1977). "Declining Terms of Trade: Myth or Reality?" Economia Internazionale 30: 46669.

Singer, H. W. (1950). "The Distribution of Gains between Investing and Borrowing Countries," American Economic Review 40: 473-85.

Spraos, J. (1980). "The Statistical Debate on the Net Barter Terms of Trade Between Primary Commodities and Manufactures," Economic Journal 90: 107-28.

Streeten, P. (1974). "World Trade in Agricultural Commodities and the Terms of Trade with Industrial Goods," in N. Islam (ed.), Agricultural Policy in Developing Countries (London: Macmillan): 207-23.

Taylor, L. (1981). "South-North Trade and Southern Growth: Bleak Prospects from a Structuralist Point of View," Journal of International Economics 11: 589-601.

Tornell, A. and A. Velasco (1992). "The Tragedy of the Commons and Economic Growth: Why Does Capital Flow from Poor to Rich Countries?" Journal of Political Economy 100 (6): 1208-31. 
Van Meerhaeghe, M. A. G. (1969). "Observation sur la Signification des Terms d'echange des pays-sousdeveloppes," Kyklos 22: 373-94.

Viner, J. (1953). International Trade and Economic Development (Oxford: Clarendon Press).

Warner, A. M. (1992). "Did the Debt Crisis Cause the Investment Crisis," Quarterly Journal of Economics 107: 1161-86.

Williamson, J. G. (1995). "The Evolution of Global Labor Markets Since 1830: Background Evidence and Hypotheses," Explorations in Economic History 32 (April): 141-96.

Williamson, J. G. (1996). "Globalization, Convergence and History," Journal of Economic History 56 (June): 1-30.

Williamson, J. G. (1998). “Globalization, Labor Markets and Policy Backlash in the Past,” Journal of Economic Perspectives 12: 51-72.

Williamson, J. G. (1999). “Real Wages, Inequality, and Globalization in Latin America before 1940,” Revista de Historia Economica XVII, numero especial: 101-42.

Williamson, J. G. (2000a). "Land, Labor and Globalization in the Pre-Industrial Third World," NBER Working Paper 7784, National Bureau of Economic Research, Cambridge, Mass. (July).

Williamson, J. G. (2000b). "Globalization, Factor Prices and Living Standards in Asia before 1940," in A. J. Latham and H. Kawakatsu (eds.), Asia Pacific Dynamism 1550-2000 (London: Routledge). Williamson, J. G. (2000c). "Real Wages and Relative Factor Prices Around the Mediterranean, 15001940," in S. Pamuk and J. G. Williamson (eds.), The Mediterranean Response to Globalization Before 1950 (London: Routledge).

Williamson, J. G. (ongoing). "Labor Supplies and Third World Inequality 1870-1940: W. Arthur Lewis Revisited."

Wood, A. (1995). “How Trade Hurt Unskilled Workers," Journal of Economic Perspectives 9 (Summer): $57-80$. 


\section{Appendix}

The export share in GDP data are mainly from A. Maddison (Monitoring the World Economy 1820-1992, Paris: OECD Development Centre Studies, 1995), extended in a few cases using M. A. Clemens and J. G. Williamson ("Where Did British Foreign Capital Go? Fundamentals, Failures and the Lucas Paradox," NBER Working Paper 8028, National Bureau of Economic Research, Cambridge, Mass. December 2000). The GDP per capita data are also taken from Maddison, sometimes extended backwards before 1914 using Clemens and Williamson. The endowment data are all taken from J. G. Williamson, "Land, Labor and Globalization in the Pre-Industrial Third World," NBER Working Paper 7784, National Bureau of Economic research, Cambridge, Mass., July 2000, Appendix. The terms of trade data are from the following sources:

Argentina 1870-1940

1870-1892, Argentina and Uruguay are assumed to have exhibited the same movements;

1892-1913, A. G. Ford, "Export Price Indices for the Argentine Republic 1881-1914," Inter-American Economic Affairs 9, 2 (Autumn 1955), Tables I and III, pp. 45-6 and 49;

1913-1940, Instituto de Estudios Economicos sobre la Realidad Argentina y Latinoamericana,

"Estadisticas de la evolucion economica de Argentina, 1913-1984," Estudios 9, 39

(July/September 1986), Table 8, p. 126.

\section{Australia 1872-1940}

1872-1900, W. Vamplew, ed., Australians: Historical Statistics (Broadway, New South Wales: Fairfax, Syme and Weldon, 1987), ITFC 81-83, col. 83, p. 194 (hereafter Vamplew); 1901-1940, Vamplew, PC 80-89, cols. 87 and 88, p. 220.

\section{Burma 1886-1923}

1886-1915, M. Shein, Burma's Transport and Foreign Trade (in relation to the economic development of the country) 1885-1914 (Rangoon: University of Rangoon Press, 1964), Table 1.C, pp. 223-5, 
232-3;

1915-1923, Thailand's Px/Pm series used as proxy.

\section{Canada 1901-1941}

M. C. Urquhart and K. A. H. Buckley, eds., Historical Statistics of Canada (Cambridge: Cambridge University Press, 1965): Export price index, Series J, cols. 84 and 108 were linked, pp. 299 and 301; Import price index, Series J, cols. 96 and 118 were linked, pp. 300 and 302.

\section{Denmark 1870-1940}

1870-1875, H. C. Johansen, Danmarks Historie Bind 9: Dansk фkonomisk Statistik 1814-1980

(Copenhagen: Gyldendalske Boghandel, 1985), Table 4.7, col. 5, p. 217 ;

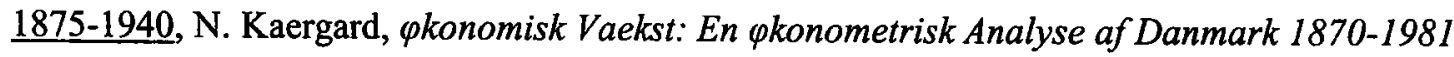

(Copenhagen: Jurist-og $\varphi$ konomforbundets Forlag, 1991), cols. 2 and 3, p. 578.

\section{Egypt 1885-1940}

B. Hansen and E. F. Lucas, "Egyptian Foreign Trade, 1885-1961: A New Set of Trade Indices," Journal of European Economic History 7 (Fall/Winter 1978), Tables la and 1b, pp.450-53, and Table 2, p. 435, export and import prices indices calculated as PFSH/QFSH, where FSH denotes a Fisher index.

France 1870-1939

1870-1896, C. P. Kindleberger, The Terms of Trade: A European Case Study (Cambridge: MIT Press, 1956), Table 2-1, pp. 12-13 (hereafter Kindleberger);

1896-1939, P. Villa, Une Analyse Macroeconomique de la France au XXeme siecle, (Paris: CNRS Editions, Monographies d'Econometrie, 1993), pp. 445-6, PEX=export prices, $\mathrm{PIM}=$ import prices.

Germany 1870-1938

$\underline{1870-1913}$ and 1921-1938, W. G. Hoffmann, Das Eachstum der Deutschen Wirtschaft seit der Mitte des 19. Jahrhunderts (Berlin: Springer-Verlag, 1965), Table 134, col. 1, p. 548; 
1914-1920, war years interpolated geometrically.

\section{Great Britain 1870-1938}

1870-1933, W. Schlote, British Overseas Trade (Oxford: Basil Blackwell, 1952), Table 26, cols. 9 and 10, pp. 175-8;

1933-1938, B. R. Mitchell and P. Deane, Abstract of British Historical Statistics (Cambridge: Cambridge University Press, 1962), pp. 331-2 (hereafter $A B H S$ ).

\section{India 1870-1940}

M. McAlpin, "Price Movements and Fluctuations in Economic Activity, 1860-1947," in D. Kumar (ed.), The Cambridge Economic History of India: Volume 2: c1757-c1970 (Cambridge: Cambridge University Press, 1983), Appendix Table 11.A.a, pp. 903-4.

Ireland 1876-1940

$\underline{1876-1923}$, no $\mathrm{Px} / \mathrm{Pm}$ series available, so the ratio of agricultural to manufactured goods prices, $\mathrm{Pa} / \mathrm{Pm}$, was used as a proxy, where Pa: 1876-1901, M. Turner, After the Famine: Irish Agriculture, 1850-1914 (Cambridge: Cambridge University Press, 1996), p. 116 for weights and pp. 264-7 for prices of oats, wheat, hay, flax, eggs, butter, pork, beef, mutton and tomatoes, and 1901-1924, Donald Nunan, "Price Trends for Agricultural Land in Ireland 1901-1986," Journal of Agricultural Economics and Rural Sociology 12 (1987), Appendix A, pp. 71-2, "agricultural products" price index;

Pm: 1876-1924, Great Britain's price index for merchandise exports, estimated by Imlah and Board of Trade, in $A B H S$, pp. 331-2;

1924-1940, Statistical Abstract of Ireland (Dublin: 1932, 1937, 1942).

Japan 1885-1938

Choki Keizai Tokei (Estimates of Long-Term Economic Statistics of Japan Since 1868, hereafter LTES) Volume 8 (Tokyo: Toyo Keizai Shinposha ,1967), Table 18, col. 3, p. 212.

\section{Korea 1910-1940}


T. Mizoguchi, "Foreign Trade in Taiwan and Korea under Japanese Rule," Hitotsubashi Journal of Economics 14 (February 1974), Table 4, p. 41 (hereafter Mizoguchi).

\section{Siam (Thailand) 1870-1940}

S. Manarungsan, Economic Development of Thailand, 1850-1950 (Bangkok: Institute of Asian Studies, Chulalongkom University, IAS Monograph No. 042, 1989), Table A.4, pp. 215-6. Px/Pm calculated as $\mathrm{Px}=$ export price for rice, $\mathrm{Pm}=$ grey shirting price (imported textiles).

Spain 1870-1935

1870-1913, L. Prados de la Escosura, De imperio a nacion: Crecimiento y atraso economico en Espana 1780-1930 (Madrid: Alianza Editorial, 1988), pp. 257-9;

1913-1935, Estadísticas Históricas de España, siglos XIX-XX (Madrid: Fundación Banco Exterior, 1989), Table 8.6, pp. 352-3.

Sweden 1870-1930

Kindlberger, Table 2-1, pp. 12-13.

Taiwan 1903-1938

Mizoguchi, Table 4, p. 41.

United States 1870-1940

1870-1935: J. G. Williamson, American Growth and the Balance of Payments 1820-1913 (Chapel Hill, NC: University of North Carolina Press, 1964), Table B.4, p. 262.

1936-1940: B. R. Moulton, "Improved Estimates of the National Income and Product Accounts for 192999: Results of the Comprehensive Revision," Survey of Current Business (April 2000).

\section{Uruguay 1870-1940}

From personal correspondence with Luis Bertola. 
Table 1

Who's in the Periphery?

Share of Primary Product Exports in Total Exports and Other Attributes Around WWI

\begin{tabular}{|c|c|c|c|}
\hline $\begin{array}{l}\text { Country } \\
\text { in Sample }\end{array}$ & $\begin{array}{l}\text { Primary-Product } \\
\text { Export Share } \\
\text { Average 1905-14 }\end{array}$ & $\begin{array}{l}\text { Unskilled Real } \\
\text { Wage }(\mathrm{GB}=100) \\
1913\end{array}$ & $\begin{array}{l}\text { GDP per capita } \\
\text { (1990US\$) } \\
1913\end{array}$ \\
\hline Denmark & $96.7 \%$ & 93 & 3,764 \\
\hline France & 36.8 & 60 & 3,452 \\
\hline Germany & 31.9 & 84 & 3,833 \\
\hline Ireland & na & 82 & 2,733 \\
\hline Spain & 75.5 & 46 & 2,255 \\
\hline Sweden & 68.6 & 89 & 3,096 \\
\hline Great Britain & 19.9 & 100 & 5,032 \\
\hline Europe average & 62.4 & 79 & 3,452 \\
\hline Argentina & 99.7 & 101 & 3,797 \\
\hline Australia & 97.0 & 116 & 5,505 \\
\hline Canada & 88.0 & 199 & 4,213 \\
\hline US & 73.3 & 154 & 5,307 \\
\hline Uruguay & 99.9 & 95 & na \\
\hline New World average & 91.6 & 133 & 4,706 \\
\hline Burma & 82.9 & 13 & 635 \\
\hline Egypt & 98.9 & 11 & 508 \\
\hline India & 82.9 & 15 & 663 \\
\hline Japan & 67.5 & 28 & 1,334 \\
\hline Korea & na & 23 & 948 \\
\hline Siam & 99.2 & 16 & 846 \\
\hline Taiwan & na & 16 & 794 \\
\hline Asia average & 86.3 & 17 & 818 \\
\hline Sample average & 79.0 & 70 & 2,706 \\
\hline
\end{tabular}

Sources: All averages are unweighted.

[1] The primary-product export share is from the Clemens and Williamson (2000) data base, which applies the Brussels 1913 classification, where primary products include "live animals," "food and drink," and "raw materials or simply-prepared products." The only significant differences between this definition and the SITC classification used by Sachs and Warner (1995b) are that ours includes iron ore and manufactured tobacco products like cigarette and cigars. The figure for Great Britain is, in fact, the UK.

[2] GDP per capita is from Maddison (1995: Table D-1, pp. 194-206), in 1990 Geary-Khamis US dollars. [3] Purchasing-power-parity adjusted real wage rates for unskilled urban males comes from: Williamson (1995: 1913, Table A2.1, p. 180) for Europe, Australia, Canada and the US; Williamson (2000b: 1910-14, Table 1.3, p. 23) for Asia; Williamson (2000c: 1909-13, Table 3.1, p. 49) for Egypt; Williamson (1999: 1910-14, Table 3, p. 119) for Argentina and Uruguay. 
Table 2

Summary of Terms of Trade Changes on Either Side of World War I (in percent)

\begin{tabular}{|c|c|c|c|c|}
\hline Ear & $\begin{array}{l}(1) \\
\text { arly } 1890 \text { s } \\
\text { to WWI }\end{array}$ & $\begin{array}{c}(2) \\
\text { Early } 1870 \mathrm{~s} \\
\text { to WWI }\end{array}$ & $\begin{array}{c}\text { (3) } \\
\text { Interwar }\end{array}$ & $\begin{array}{l}\text { (4) } \\
\text { Regime Switch } \\
(3)-(1)\end{array}$ \\
\hline & & Center & & \\
\hline \multirow[t]{2}{*}{ Land Scarce Europe } & 0.9 & 1.9 & 11.1 & 10.2 \\
\hline & & Periphery & & \\
\hline \multicolumn{5}{|l|}{ Land Abundant New World } \\
\hline with Argentina and Uruguay & 16.3 & 45.1 & 3.5 & -12.8 \\
\hline without Argentina and Uruguay & 10.7 & 25.7 & 7.8 & -2.9 \\
\hline \multicolumn{5}{|l|}{ Land Abundant Third World } \\
\hline with Argentina and Uruguay & 21.1 & 48.5 & -4.0 & -25.1 \\
\hline without Argentina and Uruguay & 19.3 & 21.2 & -4.8 & -24.1 \\
\hline \multirow[t]{2}{*}{ Land Scarce Third World } & -18.4 & 9.5 & -23.1 & -4.7 \\
\hline & & Addendum & & \\
\hline Average Land Abundant Countries & 17.6 & 37.1 & 0.4 & -17.2 \\
\hline Average Land Scarce Countries & -3.9 & 3.4 & 0.8 & 4.7 \\
\hline
\end{tabular}

Source: Williamson (2000a), Table 2, calculated from his Appendix Tables 1 and 2, unweighted. Land Abundant New World =Australia, Canada, and USA; Land Abundant Third World = Burma, Egypt, India, and Thailand; Land Scarce Third World = Japan, Korea, and Taiwan; Land Scarce Europe $=$ Great Britain, Denmark, Ireland, Sweden, France, Germany and Spain. Early $1890 \mathrm{~s}=1890-94$ (except Taiwan, which is 1895-99), WWI $=1910-14$, Early $1870 \mathrm{~s}=1870-74$ (with smaller sample), and Interwar=1910-14 to 1935-39 (except Ireland, which is 1920-24, and excluding Burma). 


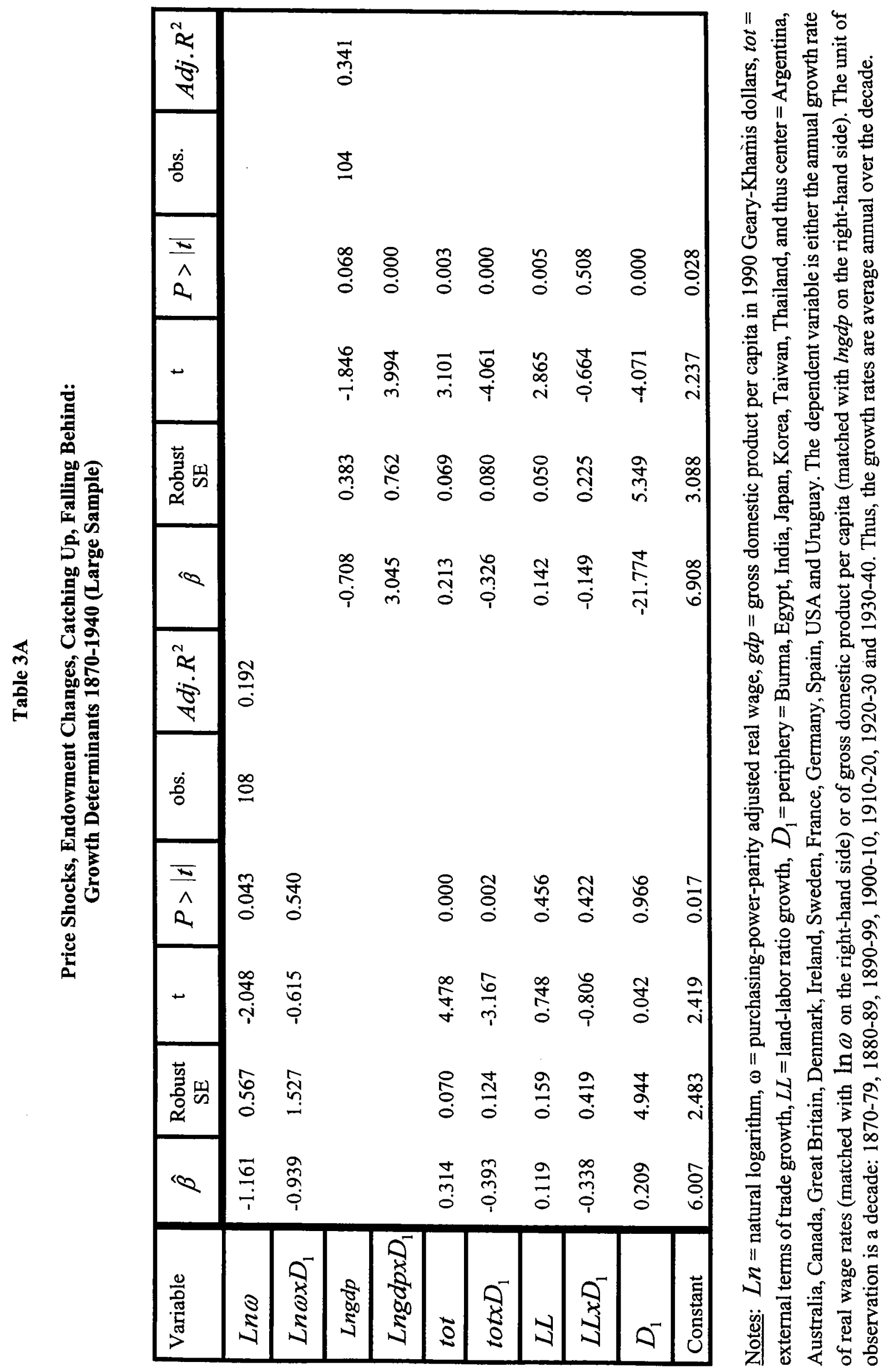




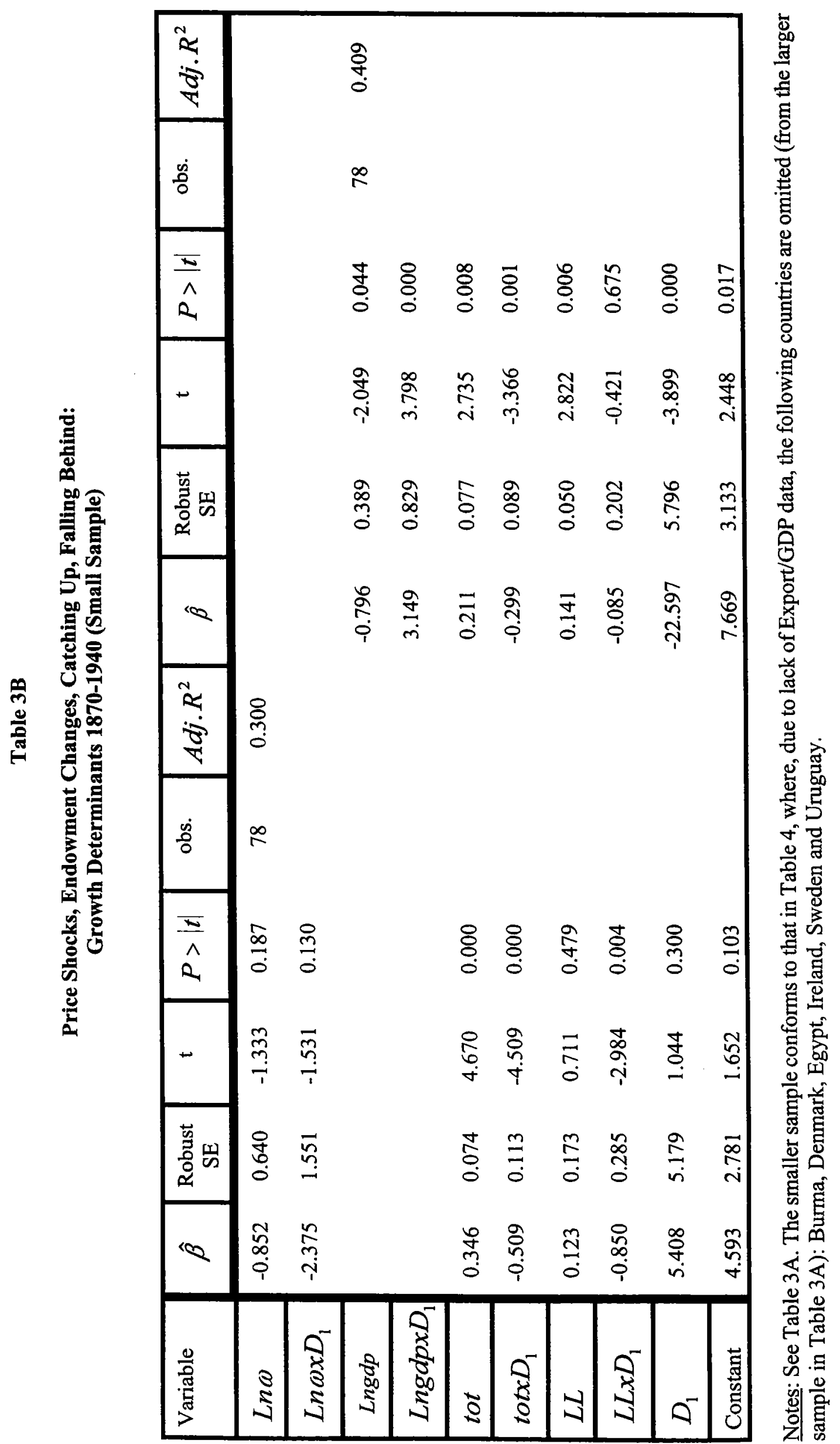




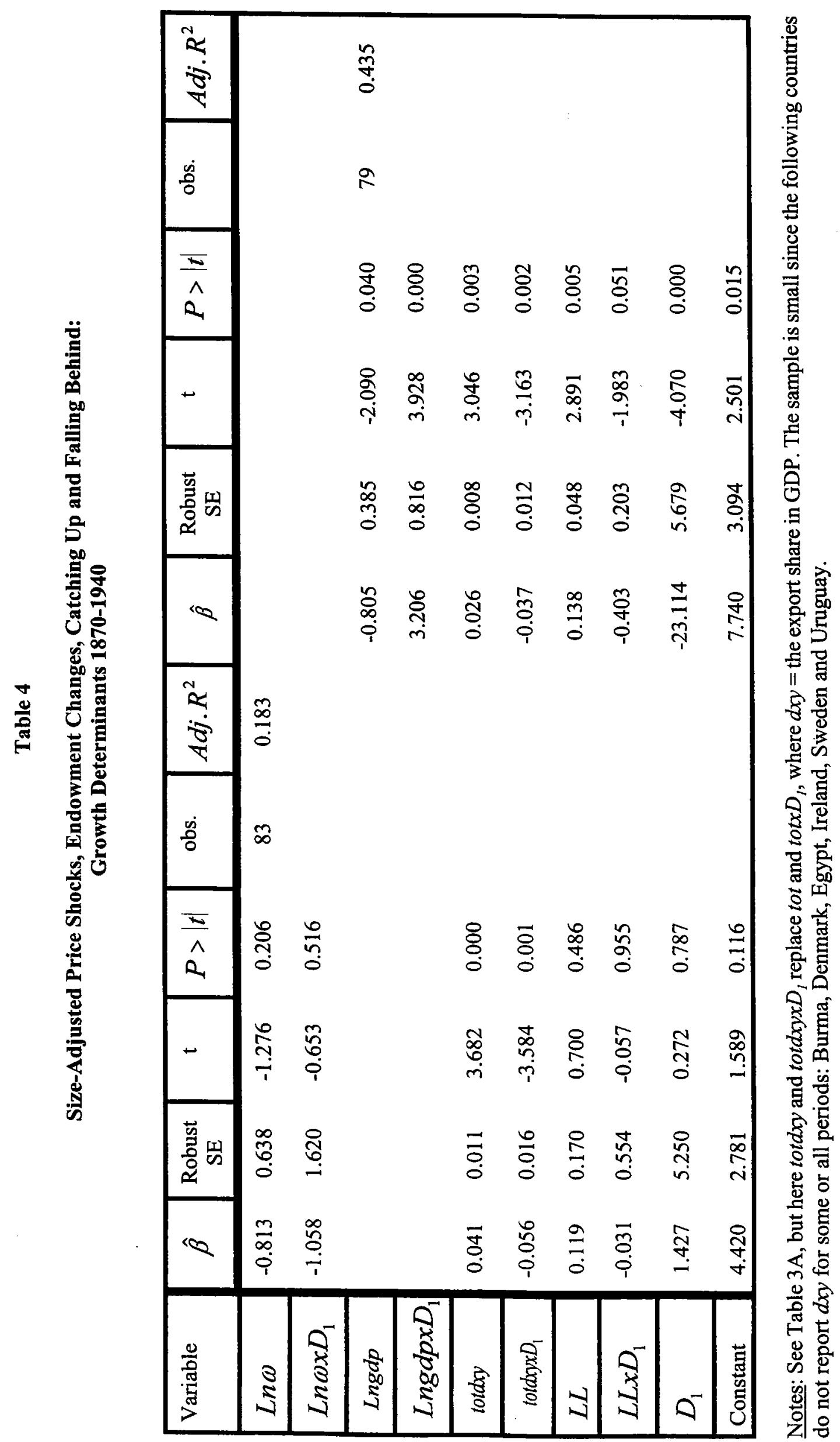




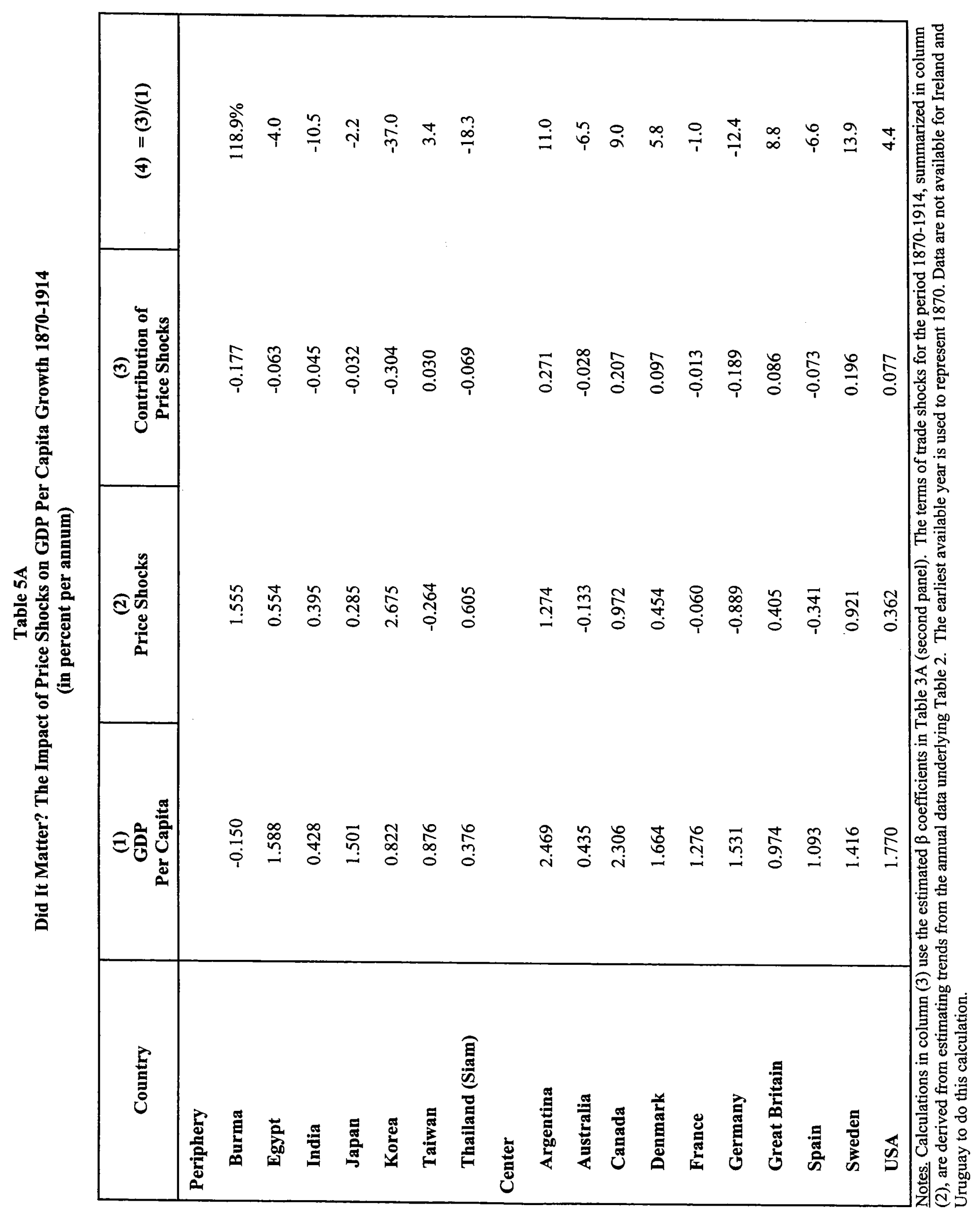




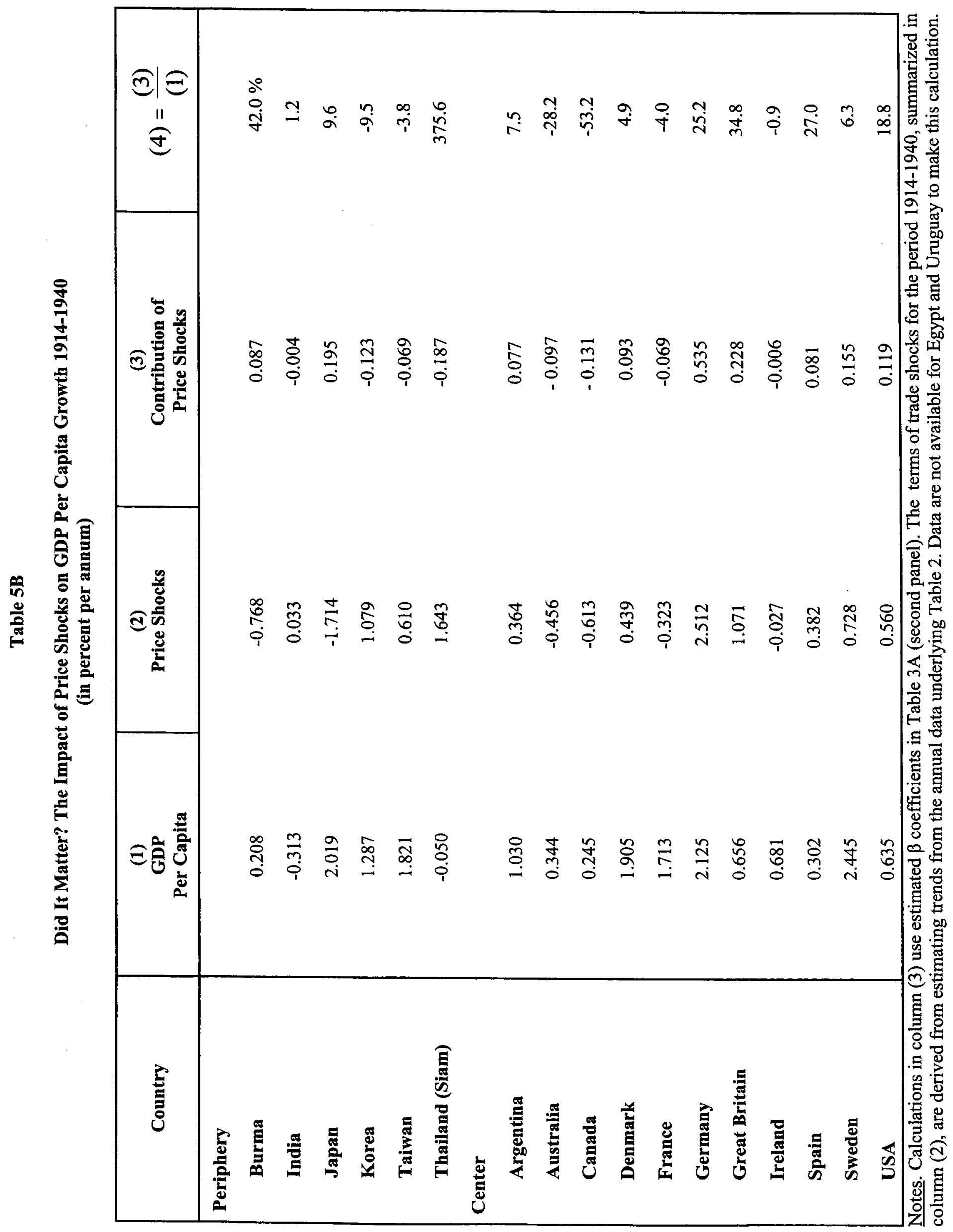


oLewis's series

$\triangle$ Prebisch's series

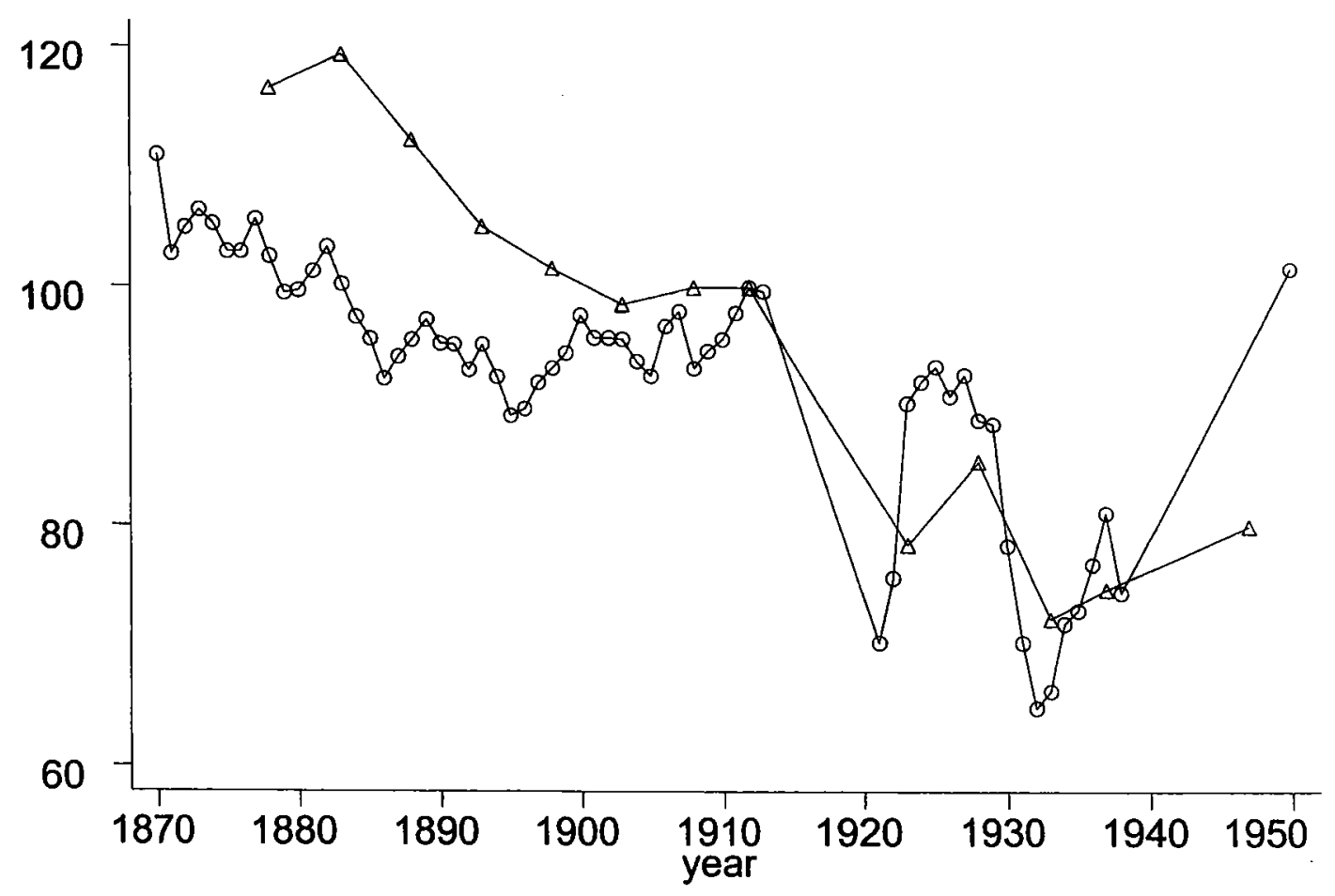

Figure 1

The Relative Price of Primary Products

According to Lewis and Prebisch 1870-1950

$(1912=100)$ 


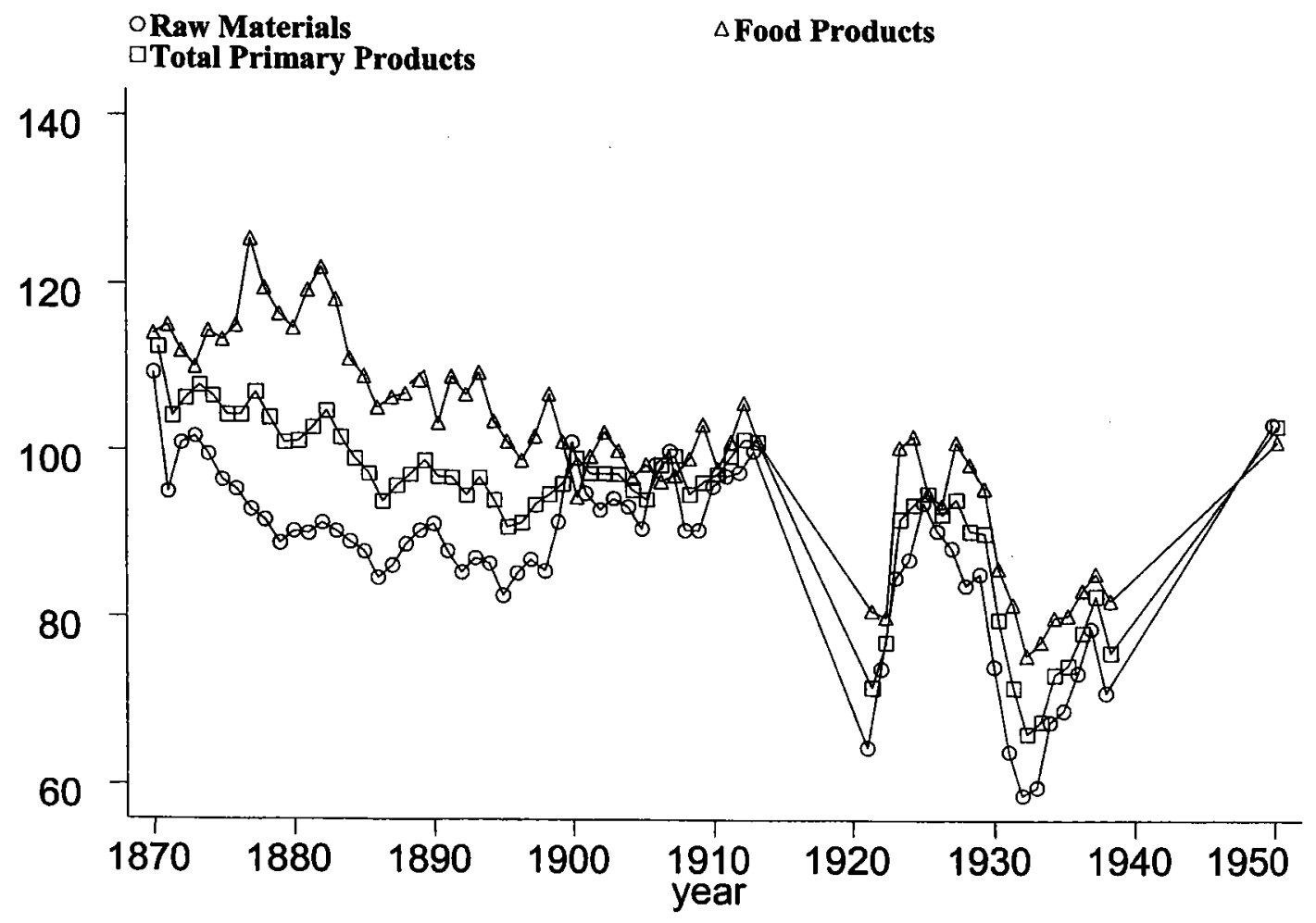

Figure 2

Three Measures of the Relative Price of Primary Products

According to Lewis 1870-1950

$(1913=100)$ 


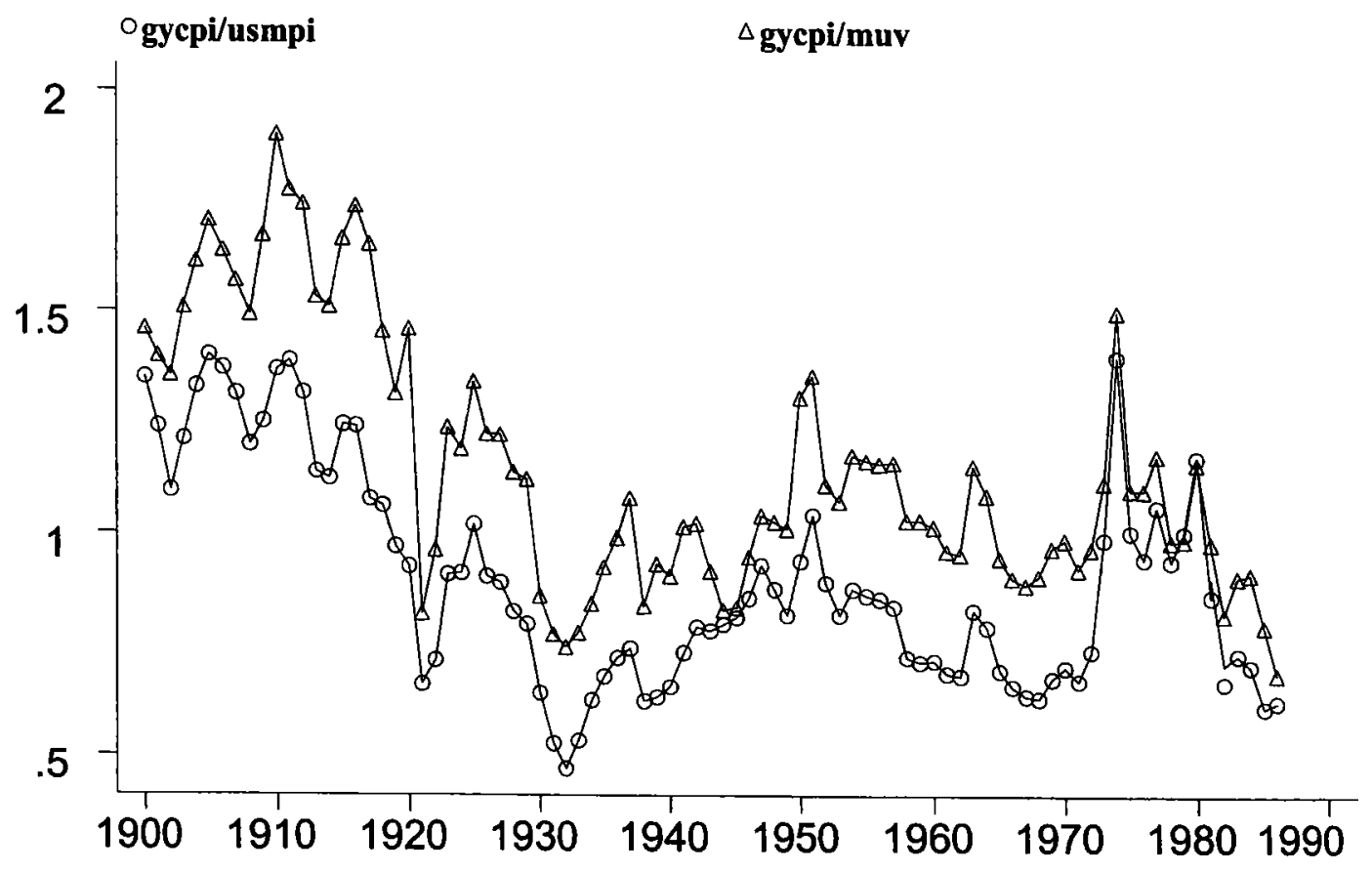

Figure 3

Relative Price of Nonfuel Primary Products 1900-1986

Grilli-Yang Indexes 


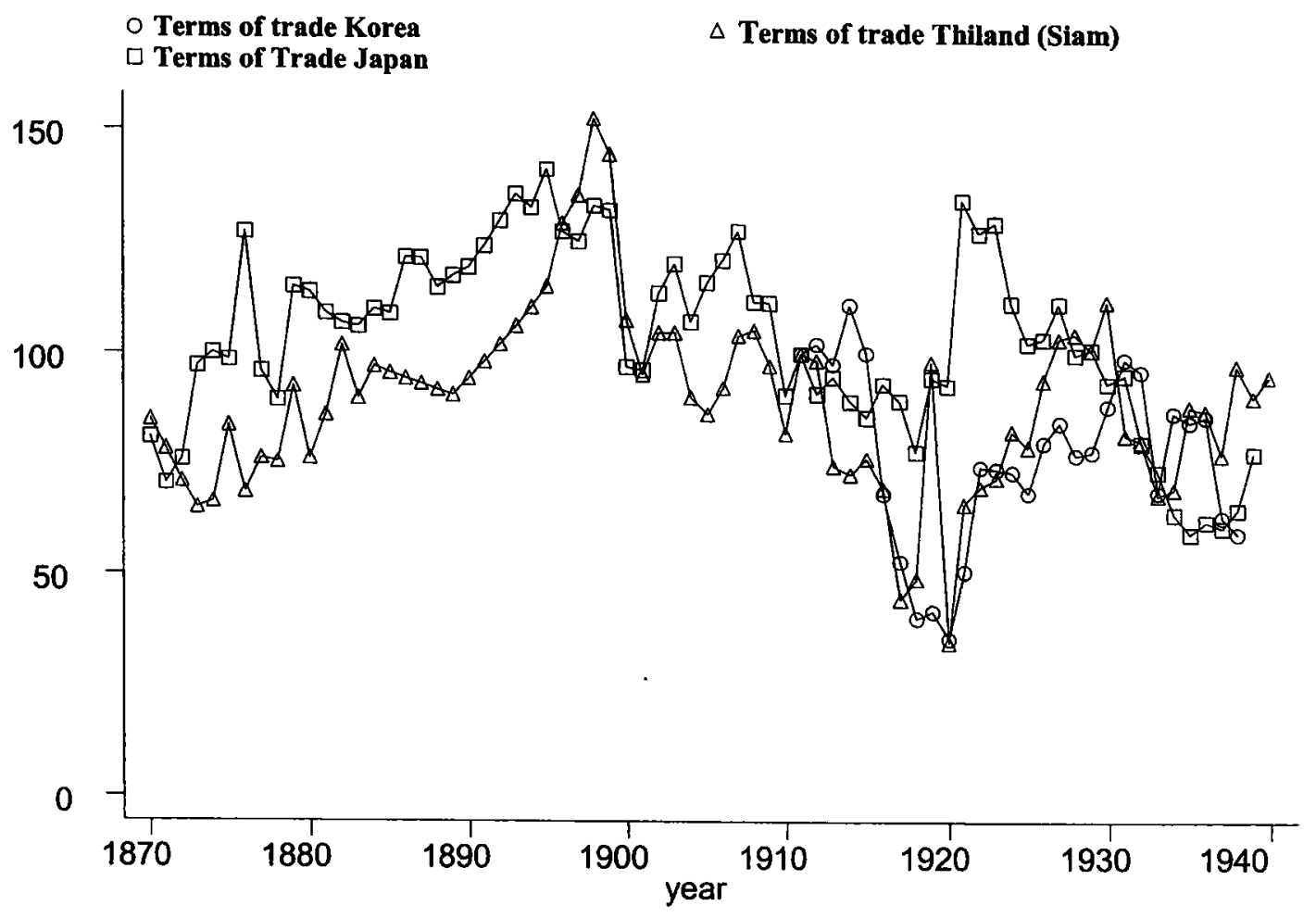

Figure 4

Terms of Trade: Japan, Korea and Thailand 
Terms of Trade Burma

$\Delta$ Terms of Trade Taiwan

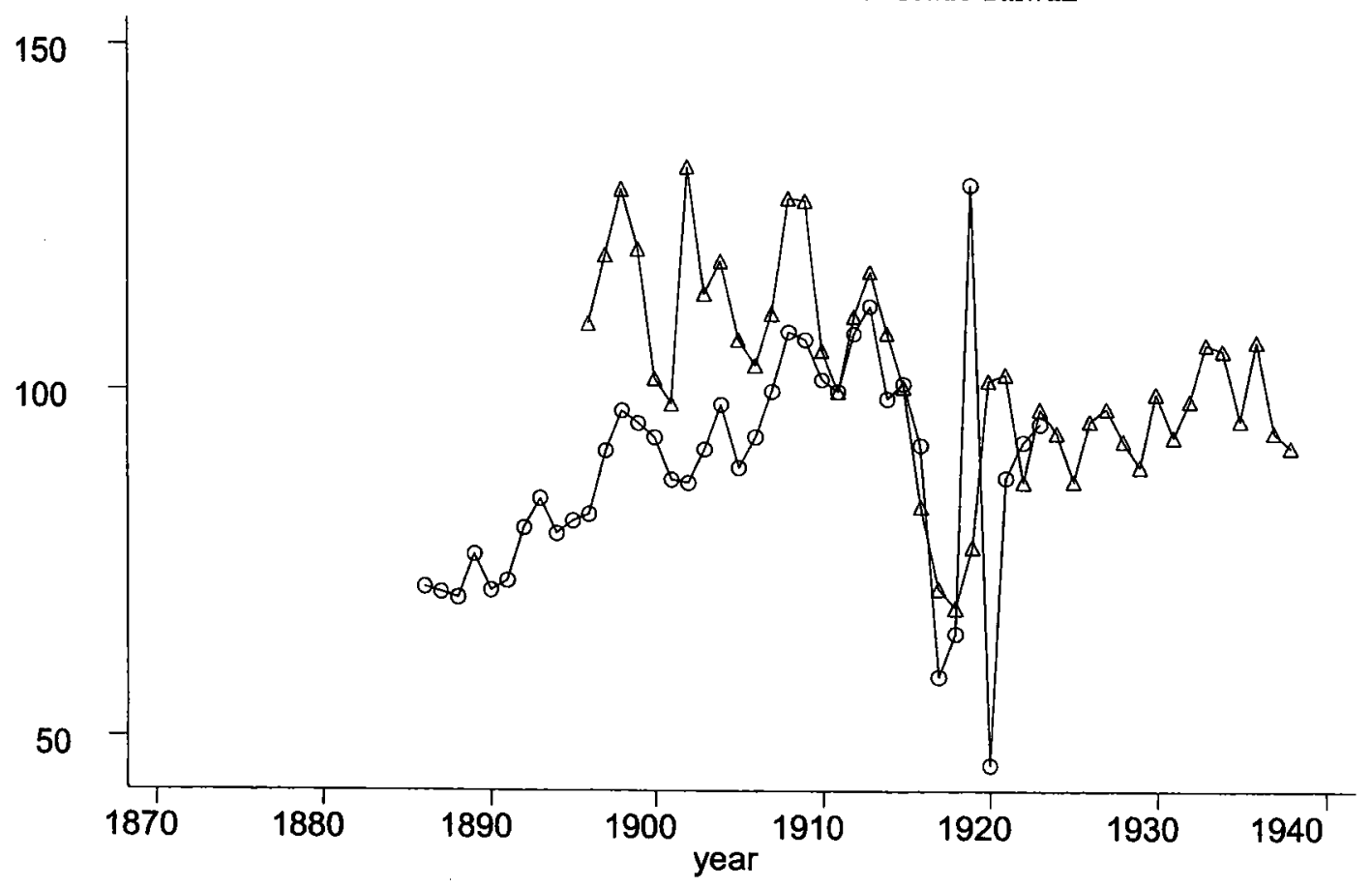

Figure 5

Terms of Trade: Burma and Taiwan 


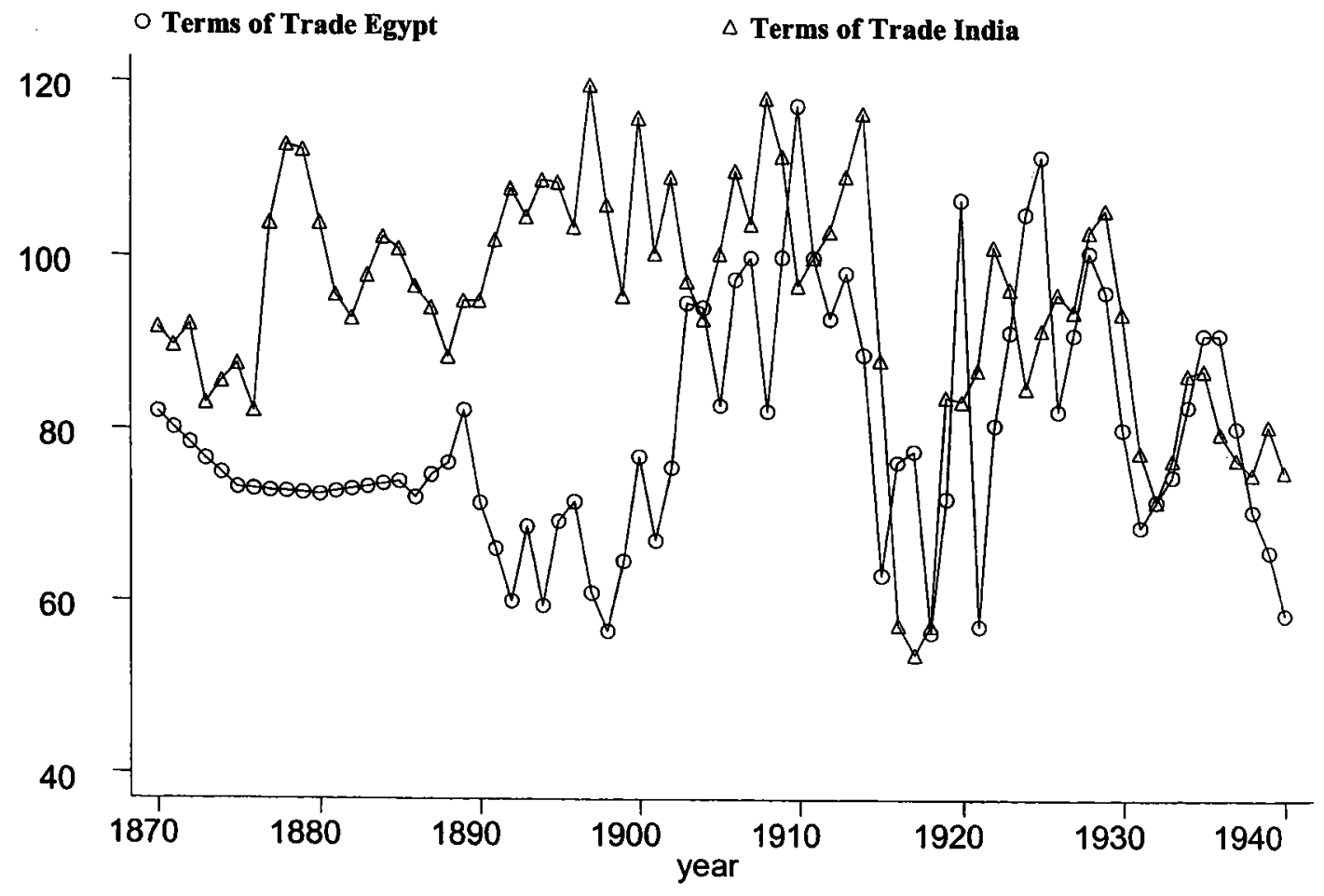

Figure 6

Terms of Trade: Egypt and India 